\title{
A Amazônia no imaginário norte-americano em tempo de guerra
}

\author{
Amazonia in the U.S. wartime imaginary
}

Seth Garfield*

REsumo

Este ensaio delineia a emergência da Amazônia no imaginário norte-americano no período da Segunda Guerra Mundial. Embora a importância geopolítica de diversificação dos mercados fornecedores de borracha e o desenvolvimento da borracha sintética tenham sido discutidos nos Estados Unidos antes do ataque a Pearl Harbor, a subsequente interdição japonesa aos mercados tradicionais do sudeste asiático levou burocratas e cientistas a se apressarem na busca de alternativas. Como em outras regiões da América Latina, as políticas de obtenção e fornecimento, durante a guerra, dividiram os progressistas adeptos do New Deal e os conservadores fiscais. Entretanto, a política de gestão norte-americana também moldou e foi moldada por mitos enraizados acerca das regiões e populações tropicais. Na época, como agora, a Amazônia era muito mais que um lugar: para os norte-americanos, era também uma pedra de toque das ansiedades mais profundas concernentes às questões de raça, classe e nação.

Palavras-chave: Amazônia brasileira; borracha; relações Brasil-EUA durante a Segunda Guerra Mundial.

\begin{abstract}
This essay traces the emergence of the Amazon in the United States wartime imaginary. Although the geopolitical importance of diversifying rubber markets and developing synthetics had been discussed in the United States before Pearl Harbor, the subsequent Japanese interdiction of traditional Southeast Asian markets sent American government officials and scientists scurrying to find alternatives. As in other regions of Latin America, wartime procurement policies in the Amazon divided New Deal progressives and fiscal conservatives, but these policies also shaped and were shaped by entrenched myths of tropical regions and populations. Then, as now, the Amazon was more than a place, but also a flashpoint for Americans for deeper anxieties concerning questions of race, class, and nation.
\end{abstract}

Keywords: Brazilian Amazon; rubber; Brazil-USA relationship during Second Word War.

\footnotetext{
* Professor Associado, Departamento de História, University of Texas. GAR 2.120, 1 Univ Sta B7000. Austin, TX 78712-0220.sgarfield@mail.utexas.edu.
} 
Este ensaio delineia a emergência da Amazônia no imaginário norteamericano anterior a Pearl Harbor e o lugar controverso que ela ocupou nas decisões políticas dos Estados Unidos durante a Segunda Guerra Mundial. A historiografia diplomática atual sobre a Era Vargas nos fornece uma visão crítica das relações bilaterais com os Estados Unidos, incluindo análises de conflitos internos à burocracia norte-americana na elaboração de políticas para o Brasil, assim como a articulação de interesses de classe dentro e fora das fronteiras nacionais. ${ }^{1}$ Contudo, distintas populações e paisagens do Brasil foram avaliadas e tratadas de forma diferente pelos responsáveis pela política dos Estados Unidos e por interlocutores particularmente interessados em controlar os recursos naturais, o território e os povos do norte do Brasil. ${ }^{2}$ Embora numerosos estudos tenham explorado a "invenção" da Amazônia por meio da análise de textos literários, os acadêmicos geralmente dedicaram pouca atenção às matrizes estruturais, institucionais e geopolíticas que embasaram essa produção cultural e que foram por ela reforçadas. ${ }^{3}$ Com base em uma linha de pesquisa que, recentemente, tem buscado fundir as abordagens metodológicas da história diplomática, ambiental e cultural, busco analisar o lugar da Amazônia no imaginário norte-americano durante a guerra. ${ }^{4}$

Nos anos que precederam Pearl Harbor, a busca por matéria-prima, defesa hemisférica e expansão das oportunidades de negócios reavivou o interesse dos Estados Unidos nos recursos naturais da Amazônia. Antes de Pearl Harbor, a enorme dependência da economia norte-americana da importação de borracha crua do Sudeste asiático levou vários altos funcionários, comentaristas e escritores a apoiar a criação de plantations de borracha na Amazônia e em outras regiões no hemisfério ocidental. O apelo da Amazônia para alguns observadores norte-americanos não estava somente em seus recursos naturais, mas também na sua promessa de aliança pan-americana e redenção espiritual.

A entrada dos Estados Unidos na guerra e a tomada dos territórios produtores de borracha do Sudeste asiático pelo Japão alteraram a natureza do engajamento político e do debate sobre a Amazônia nos Estados Unidos. A ameaça de uma iminente escassez da borracha levou o governo a intervir de forma decisiva, tanto internamente como na Amazônia, a fim de maximizar a oferta: internamente, o governo dos Estados Unidos subsidiou a criação de uma indústria da borracha sintética; na Amazônia, sua prioridade se deslocou da pesquisa botânica e do desenvolvimento de plantations para a expansão do comércio da borracha silvestre. Como em outras regiões da América Latina, porém, as políticas de obtenção de matéria-prima durante a guerra continua- 
ram altamente controvertidas. Nos Estados Unidos, os liberais duvidavam de que o aumento das exportações da América Latina durante a guerra pudesse, por si só, atender às crescentes aspirações regionais por desenvolvimento industrial e por um padrão de vida mais elevado, além das necessidades econômicas norte-americanas no pós-guerra. Por isso, defendiam que o governo dos Estados Unidos apoiasse uma modesta industrialização, a aplicação de leis trabalhistas e a expansão do comércio complementar de commodities na América Latina, como forma de modernizar economias "coloniais" e promover a ascensão social. Os conservadores, porém, buscavam restringir as iniciativas do governo norte-americano, durante a guerra, à obtenção de matériaprima através dos canais de negócios já existentes, em detrimento de reformas socioeconômicas. ${ }^{5}$ Eles criticaram duramente o uso da influência política norte-americana e da ajuda econômica para melhorar as condições sociais na Amazônia, apontando essas medidas como violação aos princípios do livremercado, assistencialismo governamental e afronta à soberania brasileira.

Embora o debate político nos Estados Unidos sobre o fornecimento de borracha pela Amazônia frequentemente se apropriasse do discurso da segurança nacional, as divisões também refletiam uma competição entre diferentes visões das paisagens e dos povos tropicais. A conflagração global havia suscitado interesse e envolvimento inéditos do governo dos Estados Unidos nos assuntos amazônicos. Porém, o imperialismo norte-americano no Caribe e no Pacífico desde a virada do século havia promovido, durante muito tempo, ideologias que infantilizavam os povos tropicais, retratando-os como incapazes de administrar os próprios recursos e desesperados por tutela política, conhecimento técnico, ajuda econômica e liderança moral vindos dos Estados Unidos. Tomando a conquista da natureza como medida do grau civilizatório, os norte-americanos olhavam com desconfiança para a região (supostamente) inculta e não-colonizada, ocupada por povos que viveriam ainda no estado de natureza. ${ }^{6}$ De fato, havia muito a Amazônia atraía o olhar de reprovação de habitantes do hemisfério Norte, que atribuíam o subdesenvolvimento da região ao peso dos fatores racial, climático e cultural. ${ }^{7}$ A recente descoberta do potencial das imensas reservas de borracha da Amazônia para a economia industrial dos Estados Unidos reavivou velhas questões imperiais sobre os trópicos. A floresta tropical poderia ser "conquistada"? Os extrativistas eram pouco produtivos porque eram explorados, ou eram explorados porque pouco produtivos? As populações da Amazônia seriam capazes ou merecedoras da ascensão social? Teria a geografia condenado os extrativistas da borracha amazônica a serem produtores marginais para o mercado mundial? 
Ou a ciência e a tecnologia ofereceriam uma nova promessa? A sociedade norte-americana se beneficiaria ou sofreria com o renascimento do comércio da borracha crua na Amazônia?

Imersas numa série de mitos históricos e preconceitos culturais relacionados à América Latina tropical (e aos Estados Unidos), as representações norte-americanas da Amazônia foram moldadas por uma mistura de imagens desgastadas: a atração pelo El Dorado, o coração das trevas tropical registrado em livros de viagem e jungle books, inclinações isolacionistas e antieuropeias, o mito construído da fronteira norte-americana, a fé no poder transformador da ciência, a sedução ou o pavor pelo emergente estado de bem-estar social. Velhas expressões sobre El Dorado ou o "inferno verde" assumiram novas conotações nessa era turbulenta, informando e sendo informadas pelas políticas públicas. Mais que um lugar, a Amazônia era também um símbolo cultural de esperança ou desilusão para os norte-americanos, uma pedra de toque para ansiedades mais profundas relacionadas a questões de raça, classe e nação. De fato, a análise histórica ressalta as forças materiais e ideológicas que moldaram a visão norte-americana da floresta tropical, revelando as mudanças e continuidades nas percepções contemporâneas da Amazônia nos Estados Unidos.

\section{A DEPENDÊNCIA NORTE-AMERICANA DA BORRACHA} Às vésperas de PeArl Harbor E A ATraÇão dA Amazônia

Em razão da abundância de recursos naturais no Brasil, de sua influência política na América do Sul, grande população de ascendência alemã e proximidade geográfica da África Ocidental, os oficiais militares norte-americanos viam o país como um ponto estratégico na resistência a ofensivas nazistas no hemisfério. Entre setembro de 1939 e dezembro de 1941, com a guerra em andamento na Europa e na Ásia, um conglomerado de agências norte-americanas tentou complementar ou substituir o Departamento de Estado para fortalecer o comércio e a aliança interamericanos, assegurar o acesso a recursos estratégicos e excluir o Eixo do hemisfério ocidental: ${ }^{8}$ a Reconstruction Finance Corporation, a Inter-American Development Commission, o Export-Import Bank, o Economic Defense Board, o Airport Development Program, o Office of Inter-American Affairs, o Departamento de Agricultura e o Departamento da Guerra. ${ }^{9}$ Inequivocamente, a guerra na Europa havia eliminado efetivamente três quintos do comércio exterior da América Latina, lançando a região numa 
profunda crise econômica. ${ }^{10}$ Contudo, o governo norte-americano também via o hemisfério ocidental como potencial fonte de matérias-primas até então fornecidas pelos ameaçados mercados do Velho Mundo.

Em 1940, os Estados Unidos, com 6\% da população do mundo e 7\% da superfície terrestre, produziam metade dos produtos industriais finais e $75 \%$ dos veículos motorizados, mas a rápida transformação de uma sociedade agrária para uma economia de produção em massa no início do século XX havia ocasionado uma dependência sem precedentes da importação de matérias-primas para sustentar a produção industrial. ${ }^{11} \mathrm{O}$ abastecimento de borracha era particularmente desafiador para os Estados Unidos. Em 1942, a borracha consumida nos Estados Unidos era 96\% natural e apenas $4 \%$ sintética. $^{12}$ Os Estados Unidos importavam do Sudeste Asiático, principalmente da Malásia Britânica e das Índias Holandesas, 98\% da borracha crua que utilizavam (Marshall, 1995, p.23). Em 1941, a importação de borracha crua nos Estados Unidos tinha chegado ao impressionante total de 1.025 mil toneladas, mais que a soma de todo o resto do mundo (Tuttle, 1981, p.65). O consumo prodigioso de borracha nos Estados Unidos resultou do avanço meteórico na tecnologia das máquinas no século XX. Assim como o ferro, o aço, o carvão e o petróleo, a borracha havia se tornado um material essencial, tanto na paz quanto na guerra, nas fábricas e nas casas, fazendas e meios de transporte, em bens produzidos em tempo de paz e em material bélico. ${ }^{13}$ Eram conhecidos mais de 40 mil usos para a borracha, mas sua principal aplicação nos Estados Unidos durante a Segunda Guerra Mundial era na indústria de pneus, em que a borracha contribuía para a revolução no transporte individual de longa distância. ${ }^{14}$ Entre 1938 e 1940, 76,6\% de toda a borracha crua consumida nos Estados Unidos foi transformada em pneus, câmaras de ar e artigos correlatos (com pneus de automóveis representando 85\% do total), equipando $27 \mathrm{mi}$ lhões de automóveis norte-americanos (Knorr, 1945, p.46).

No seu sentido mais básico, a borracha crua refletia aquilo que Fernando Coronil havia denominado a "divisão global da natureza", que tinha reservado às regiões do chamado Terceiro Mundo um lugar distinto na divisão internacional do trabalho. ${ }^{15}$ Como as seringueiras requeriam um clima tropical e úmido, com temperaturas entre, aproximadamente, 21 e 32 graus e um nível pluviométrico de cerca de 2.500 milímetros ao ano, o "cinturão da borracha" restringia-se a uma faixa relativamente estreita, entre dez graus ao norte e ao sul do Equador, na Ásia, na África e na América Latina. Embora centenas de seringueiras, arbustos, plantas e vinhas crescessem nos Estados Unidos sendo a guaiule, nativa do Sul do Texas e do Norte do México, a mais promis- 
sora - , a quantidade de borracha no látex encontrado na maioria das regiões temperadas era muito mais baixa que nas plantas tropicais, e os encargos trabalhistas eram muito maiores nos Estados Unidos. ${ }^{16} \mathrm{~A}$ escolha recaiu sobre a hevea brasiliensis, uma árvore nativa da Amazônia que sustentara o crescimento espetacular da região entre 1850 e 1910, mas cuja primazia foi sumariamente minada pelos ingleses, que contrabandearam sementes de seringueira em 1876 para replantar em suas colônias asiáticas; cultivada em grandes plantations e por pequenos agricultores, a seringueira asiática produzia maior volume de látex a custo menor que a borracha amazônica. Em 1940, de acordo com as estimativas dos Estados Unidos, a produção anual de borracha no vale do Amazonas totalizava apenas entre 16 mil e 18 mil toneladas. ${ }^{17}$

Como aponta David Harvey, mercados complexos tendem a ocultar dos consumidores as regiões geográficas (e as relações sociais) que produzem commodities. ${ }^{18}$ Porém, a inquietante dependência do látex asiático tornava $\mathrm{o}$ comércio da borracha crua, de tempos em tempos, politicamente controverso nos Estados Unidos. Na década de 1920, políticas restritivas implantadas pelos ingleses sobre a produção de borracha asiática provocaram fortes reações nacionalistas nos Estados Unidos, que dependiam da borracha estrangeira. Isso levou o governo norte-americano a pesquisar mercados alternativos e também preparou o terreno para os investimentos em larga escala de Henry Ford em plantations de borracha na Amazônia brasileira. Da mesma forma, nos anos que antecederam Pearl Harbor, alguns altos funcionários do governo dos Estados Unidos alertaram sobre os efeitos catastróficos que a perda dos mercados asiáticos de borracha causaria na economia e na capacidade de mobilização militar do país. Em 1939, o economista Eliot Janeway escreveu:

A economia americana e, com ela, a defesa americana não podem operar sem borracha, e é estanho que, atualmente, ela não possa ser obtida em quantidade adequada senão das colônias britânicas e holandesas do Sudeste asiático. E, hoje, o Japão controla as rotas comerciais entre a costa Leste dos Estados Unidos e os Estreitos da Malásia... Lá se encontra, pronta para ser entregue ao Japão, uma arma mais segura e mais poderosa do que um ataque naval imprudente... (ver Marshall, 1995, p.xi)

No ano seguinte, um relatório do Conselho de Equipamentos de Guerra do Exército e da Marinha dos Estados Unidos dizia: "parece não haver dúvida de que a borracha é quase tão essencial à defesa nacional quanto a pólvora [ou] os explosivos ... a defesa nacional seria colocada em risco se o abasteci- 
mento por fontes externas fosse cortado" (ver Marshall, 1995, p.13). Essa ameaça se tornou mais grave a partir da invasão nazista da Europa Ocidental na primavera de 1940, com ataques de submarinos alemães a navios no Atlântico e medo crescente de que os japoneses pudessem interditar o suprimento asiático de borracha.

Críticos nos Estados Unidos sugeriram três opções principais para reduzir a dependência de fontes do Sudeste asiático — o armazenamento de estoques domésticos de borracha importada, o desenvolvimento de uma indústria sintética e a diversificação geográfica da aquisição de borracha crua. Com seus milhões de seringueiras silvestres, a Amazônia atraiu o olhar de observadores norte-americanos, representando a possibilidade da terceira opção para assegurar o suprimento de borracha: a diversificação dos mercados tradicionais. Como John Gunther alertava em 1940: "Se a guerra se estender ao Extremo Oriente e impedir aos Estados Unidos o acesso a suas fontes normais de borracha, quinina, cânhamo e estanho, nos restará apenas rezar para que a América Latina seja uma substituta". ${ }^{19} \mathrm{E}$, como outra autora norte-americana indagava às autoridades brasileiras em 1940:

A borracha, há muito o mais importante produto da Amazônia, é indispensável na indústria mundial de hoje. Com a guerra na Europa e os movimentos japoneses no Pacífico Sul, e as consequentes ameaças do Japão de cortar nosso comércio com as Índias Orientais Holandesas e com a Malásia Britânica, por que os Estados Unidos não se voltariam para seu país como sua principal fonte de borracha? ${ }^{20}$

A história ambiental pioneira de Warren Dean sobre a borracha amazônica documenta os esforços intermitentes das administrações Vargas e Roosevelt para criar plantations de borracha no Brasil no início da década de 1940. No dia 22 de junho de 1940, o Congresso dos Estados Unidos aprovou uma lei que destinava 500 mil dólares para o Departamento de Agricultura (USDA), para o desenvolvimento da produção de borracha no hemisfério ocidental. O Bureau of Plant Industry e o Office of Foreign Agricultural Relations montaram um amplo programa para pesquisar o cultivo sistemático de borracha, com o objetivo principal de combater o Microcylus ulei, vulgarmente conhecido como "mal-das-folhas" sul-americano, fungo que, historicamente, atacava as plantações de borracha no hemisfério ocidental. Acordos de cooperação foram assinados com catorze países da América Latina e também com várias companhias comerciais; missões exploradoras foram enviadas pa- 
ra áreas promissoras, buscando avaliar se elas eram próprias para o cultivo da seringueira e colher informação sobre as condições de saúde e o nível salarial, além de produzir pesquisas topográficas, mapas e fotografias; botânicos do USDA foram enviados para a América Latina; seções experimentais e demonstrativas foram estabelecidas na Amazônia brasileira, na América Central e no Caribe para reunir e propagar clones altamente produtivos da seringueira e criar variedades resistentes a doenças; sprays fungicidas contendo cobre insolúvel foram aplicados, com sucesso, para controlar o "mal-das-folhas" em mudas criadas em viveiros experimentais. No Brasil, um acordo entre o Ministério da Agricultura e o USDA foi assinado em outubro de 1940, autorizando a operação de uma equipe de pesquisa na Amazônia e o estabelecimento de um viveiro experimental em terrenos do Instituto Agronômico do Norte (IAN), criado no ano anterior, em Belém, como parte da iniciativa de Vargas de trazer a agricultura científica e o saneamento para o vale amazônico. Atenção especial foi dada à obtenção de variedades mais produtivas da seringueira, para compensar as vantagens do baixo custo do trabalho asiático. Em 1942, já havia mais de um milhão de mudas sendo testadas no IAN e quinze milhões em toda a América Latina. ${ }^{21}$ É certo que os "acordos da borracha” representaram uma mudança significativa para o USDA, que, historicamente, enviara missões a países estrangeiros para analisar a competição e a demanda por commodities agrícolas afetadas pelas exportações agrícolas da América Latina, conduzir estudos sobre insetos daninhos ou potencialmente prejudiciais às plantações dos Estados Unidos e participar de conferências internacionais e sociedades científicas. Os acordos da borracha, porém, eram estratégicos para os Estados Unidos, porque tinham como objetivo a oferta de aconselhamento técnico e de equipamentos para aumentar a produtividade de uma commodity que o país não produzia e da qual precisava para atender suas necessidades básicas. ${ }^{22}$

Como nota Dean, os cientistas não conseguiram gerar seringueiras resistentes ao "mal-das-folhas" na Amazônia, eliminando as esperanças de tornar a região capaz de competir no mercado global da borracha. Contudo, ao estudar as inovações botânicas e as dificuldades do cultivo de seringueiras no Brasil, Dean deixou de examinar o quadro político e cultural mais amplo nos Estados Unidos que alimentou (ou negou) as perspectivas de um ressurgimento do comércio de borracha na Amazônia. Metodologicamente, o enfoque adotado por Dean reflete uma compreensão mais restrita da história ambiental como um estudo dialético das condições "naturais" que governam o relacionamento entre seres humanos e o ecossistema, em detrimento de um 
exame mais amplo do caráter predominantemente social dessas relações. ${ }^{23}$ Mais instrutivo, ao abordar as formas em que os usos e significados da natureza amazônica se constroem culturalmente e se embasam historicamente, é o insight do antropólogo Arjun Appadurai, o qual postulou que "as coisas não têm significados à parte daqueles que as transações, atribuições e motivações dão a elas". ${ }^{24}$ Entre seus defensores nos Estados Unidos, a recriação da natureza amazônica prometia novas direções para a economia norte-americana e para o comércio interamericano, comunhão entre as culturas e até regeneração espiritual; de fato, para os isolacionistas, a autossuficiência hemisférica em matéria-prima poderia evitar o apocalipse. Os significados salvacionistas mais profundos que os norte-americanos atribuíram à floresta amazônica ou dela derivaram refletem as visões políticas e os mitos culturais estabelecidos na sua própria sociedade, tanto quanto na paisagem tropical.

A lei de desenvolvimento hemisférico da borracha foi concebida pelo vice-presidente Henry A. Wallace, culminando seus esforços como secretário da agricultura (1933-1940) para aumentar o comércio da América Latina com os Estados Unidos. Wallace havia defendido internamente, como necessárias ao sucesso do New Deal, políticas que favoreciam o manejo científico da agricultura, as máximas produtividade e distribuição, a promoção do comércio e da cooperação internacionais através de baixas tarifas e a aplicação de leis antitruste para desafiar os monopólios industriais. ${ }^{25}$ Nesse sentido, Wallace era um antigo defensor do desenvolvimento de produtos tropicais e outras culturas complementares na América Latina para aumentar o comércio com os Estados Unidos. Embora a agricultura respondesse por $80 \%$ da receita de exportações na América Latina entre 1930 e 1940, metade dessas culturas competia com produtos dos Estados Unidos; e, enquanto as importações norte-americanas de produtos tropicais e semitropicais antes da guerra haviam chegado a 236 milhões de dólares, a América Latina fornecia menos de 16 milhões desse total. No Oitavo Congresso Científico Americano em Washington, em maio de 1940, Wallace propôs a criação de um instituto de pesquisa agrícola interamericano para promover o desenvolvimento da agricultura tropical nas Américas. No verão de 1940, Wallace criou o Office of Foreign Agricultural Relations (FAR) para estimular o treinamento em agricultura e promover a diversificação de cultivos, enviando especialistas para várias repúblicas latino-americanas. ${ }^{26}$

A borracha amazônica era um exemplo perfeito de uma commodity tropical produzida no hemisfério ocidental e subutilizada pela indústria norteamericana. Em 1938, por exemplo, os Estados Unidos gastaram um milhão de 
dólares na compra de borracha de toda a América Latina, enquanto $119 \mathrm{mi}$ lhões foram gastos com a Ásia. ${ }^{27} \mathrm{Um}$ artigo publicado na Agriculture in the Americas (publicação do FAR) apontava:

O estabelecimento de uma bem-sucedida agroindústria [da borracha] no hemisfério ocidental, paralelamente ao incentivo de outras culturas complementares, representaria um significativo avanço nos níveis econômico, financeiro e social em muitos países. Aproveitando os muitos recursos da América Latina, estaremos dando às nações ao Sul de nós o poder de compra necessário para criar uma sólida fundação para duradouras relações comerciais. É um postulado econômico: o comércio não é uma via de mão única. Para poder exportar, precisamos importar, e não podemos vender para aqueles que não têm dólares para comprar de nós. (Apodaca, 1941, p.11)

Em Pan America (1940), o jornalista radical Carleton Beals endossou também um "programa de visão de longo prazo" para a produção e diversificação geográfica de materiais essenciais, particularmente no hemisfério ocidental como um todo. No caso da borracha, Beals lamentou a cumplicidade dos fabricantes norte-americanos de manufaturas e das políticas de comércio dos Estados Unidos no sustento de práticas monopolistas europeias que prejudicavam os consumidores norte-americanos. Ele criticou:

se o preço médio dos últimos 25 anos for levado em conta, descobrir-se-á que teria sido mais barato pagar mais pela borracha brasileira, e que poderíamos mesmo ter gastado bilhões para financiar toda uma indústria da borracha na América do Sul e também uma indústria sintética e, como nação, ainda ter dinheiro no bolso.

Beals argumentava que, “com tempo e planejamento cuidadoso", a América Latina poderia fornecer "toda a borracha que usamos". Ainda que não acreditasse que a extração da borracha crua no Brasil pudesse aumentar a ponto de compensar um corte imediato no suprimento asiático, argumentava que "não há razão para que o hemisfério ocidental não deva se tornar completamente independente do Oriente em relação à borracha”. Em parte, Beals contrapunha o apelo da natureza generosa à falácia da degeneração tropical: "A seringueira se originou neste hemisfério, o clima e o solo são apropriados e o transporte é facilmente feito nas grandes bacias hidrográficas da América do Sul". Porém, acima de tudo, ele defendeu políticas governamentais que estabelecessem um sistema de cotas mínimas, abatimentos, preferências tari- 
fárias, assistência técnica e contratos de longo prazo com governos e indústrias estrangeiros, que possibilitariam à borracha latino-americana competir com as exportações asiáticas. Ele afirmou:

Não deveríamos nos preocupar se o aumento na produção de borracha é obtido através do capital federal ou privado ou latino-americano. O importante é ter uma quantidade definida e garantida de borracha produzida aqui no Novo Mundo, livre do monopólio por uma única potência, garantindo preços estáveis para uma de nossas principais indústrias, trazendo segurança contra a escassez em tempos de guerra, ajudando a criar um comércio bilateral com a América Latina e criando uma base mais democrática para essas relações comerciais, laços políticos e solidariedade continental. (Beals, 1940, p.xi-xiv, 454-476, 499-500)

Dada a centralidade da fronteira na formulação de classe, gênero e identidades nacionais nos Estados Unidos, para não falar de suas ideologias imperialistas na América Latina, não surpreende que observadores tendessem a dourar a Amazônia através de suas próprias lentes de familiaridade cultural. ${ }^{28}$ Na realidade, o uso do termo "fronteira" pelos norte-americanos nessa época para descrever a Amazônia em si mesmo é revelador do desencontro cultural do pan-americanismo, uma vez que o português brasileiro não conta com termo análogo. ${ }^{29}$ Seria realmente complicado para os autores norte-americanos entender ou explicar a seus leitores as especificidades do comércio da borracha na Amazônia - com seu sistema de endividamento que ligava comissários (aviadores), seringalistas e seringueiros. Assim, em seu elogio dos seringueiros brasileiros como "os verdadeiros pioneiros do vasto interior", Frances Ahl afirma: "Eles são os William Beans e James Harrods, os John Seviers e James Robertsons, os Daniel Boones e David Crocketts, os Marcus Whitmans e Kit Carsons. Eles estão avançando, lentamente conquistando as vastas fronteiras da Amazônia" (Ahl, 1941, p.157). Contudo, a descrição de Ahl sugeria que a Amazônia, povoada por heróis populares norte-americanos com uma roupagem diferente, estava destinada a seguir a mesma trajetória histórica da fronteira norte-americana, com seus pequenos proprietários de terra e intrépidos pioneiros.

Porém, mais intrigantes que doses de previsível autorreferência são as várias formas como os norte-americanos imaginaram a "fronteira" amazônica entre o final da década de 1930 e o início dos anos 40. Para alguns observadores norte-americanos, o valor de uso da fronteira amazônica estava em suas recompensas materiais. Imagens da Amazônia como o El Dorado esperando 
seu conquistador ianque foram prontamente recicladas. Ahl, censurando "o escritor medíocre [que] exagera enormemente os terrores da selva", afirmou:

nenhum ser humano pode se dar conta das oportunidades de adquirir riqueza e dinheiro no grande vale do Amazonas, para aqueles dispostos a fazer o sacrifício imposto por um clima tropical e as difíceis condições de vida... enormes riquezas se encontram na floresta equatorial, oferecendo oportunidades de lucro incomparáveis em todo o mundo. (Ahl, 1941, p.18-19, 119)

E, num relatório de 1939 sobre as condições econômicas da América Latina, Nicholas Roosevelt, enviado para a região por interesses empresariais norte-americanos, mencionava a Amazônia como um exemplo perfeito de uma região onde o futuro transporte aéreo prometia reduzir os altos custos para se fazer negócio, que tradicionalmente mantiveram baixo o padrão de vida e aumentaram despesas para investidores e produtores. ${ }^{30}$ Essas representações atualizaram as descrições da Amazônia como um El Dorado, e da América Latina como um "amplo reservatório de riquezas naturais com o potencial para servir como uma nova fronteira e o centro de uma nova civilização". ${ }^{31}$

No entanto, a transformação da Amazônia de selva em fazenda, sob a égide da ciência moderna e do governo ilustrado, prometia também um futuro democrático e um rejuvenescimento espiritual para a "humanidade" (Pike, 1998, p.1, 21). Transpondo para o Sul o mito turneriano da regeneração moral da fronteira, Earl Parker Hanson proclamou, entusiasmado, em sua Jornada para Manaos [1938], sobre o futuro da Amazônia:

O homem comum dificilmente será capaz de imaginar quão difundida é a ideia, mesmo nos Estados Unidos, de que a colonização da América do Sul daria novo fôlego ao nosso mundo civilizado. Porém, tendo me interessado, vejo-me a cada momento confrontado com o argumento romântico de que a conquista dos espaços vazios na América do Sul faria pelo hemisfério ocidental o mesmo que a conquista do Oeste fez pelos Estados Unidos num período crítico... a colonização do interior sul-americano daria um estímulo milagroso à prosperidade e à consequente liberação de nossos espíritos reprimidos.

É bem verdade que Hanson enfatizou a importância de políticas públicas para promover a pesquisa agrícola e desenvolvimento em saúde, nutrição e educação, mas sua postura científica ainda trazia latente o ideal romântico da Amazônia colonizada como um espaço redentor: 
quando o mundo sair do impasse atual entre filosofias sociais e econômicas amargamente opostas, quando a nuvem de medo e confusão em que hoje vivemos houver se dissipado, assistiremos a uma liberação de energia tão grande que, como a renascença que se seguiu à última Idade Média, enviará pioneiros para todos os cantos selvagens do mundo, assim como a liberação da energia russa já permitiu, na Sibéria, a maior expansão para o Norte jamais vista pelo mundo. ${ }^{32}$

Da mesma forma, Carleton Beals proferiu uma visão milenarista em $\mathrm{Fu}$ ture of the Amazon (1941), antecipando que o acesso às riquezas naturais da Amazônia revelaria "novos segredos para o domínio humano da Terra" e elevaria o "gozo material e espiritual nela experimentados". Beals afirmou:

Certamente, até que o homem faça uma investida determinada e científica nessa região, o Novo Mundo não terá realizado por inteiro seu potencial; não se poderá dizer que a América do Sul alcançou sua maturidade ou encontrou seu verdadeiro lugar como um dos grandes continentes ativos da Terra. Está aqui uma das últimas grandes fronteiras físicas do homem. Domar este grande deserto ${ }^{a}$ vai exigir a mais extensiva aplicação do conhecimento político e econômico, os mais avançados instrumentos da ciência e as mais nobres intenções de aprimoramento humano.

Beals saudava novas técnicas científicas, como a medicina tropical, o condicionamento do ar (que permitiria "grandes cidades com ar condicionado se erguerem às margens do Amazonas e de seus tributários"), a melhora do transporte fluvial com a construção de canais e barragens; o cultivo de variedades de seringueiras mais produtivas e resistentes a doenças, "desenvolvidas e estabilizadas em pequenas propriedades", e o avião. Demolindo teorias climáticas e raciais que povos do hemisfério Norte haviam historicamente invocado para explicar as desigualdades globais e legitimar o colonialismo, Beals exortava:

Mobilizemos as forças do Novo Mundo para uma incursão concertada, planejada e científica à bacia amazônica. Que a iniciativa não tenha nenhuma marca do imperialismo. Que ela seja feita em espírito de cooperação dos povos livres para expandir o bem-estar da humanidade. Qualquer que seja o destino da Europa, podemos fazer uma nova América. ${ }^{33}$

Contudo, ao sacralizar a Amazônia, colocando-a como o lugar da redenção pan-americana, cuja consagração eludia a capacidade tecnológica e a 
"maturidade" do Brasil sozinho, Beals prefigurava um mantra popular do pós-guerra no hemisfério Norte: a noção da Amazônia como patrimônio ambiental da "humanidade", ao invés de um território soberano de diferentes nações sul-americanas.

Para o America First Committee, formado em setembro de 1940 para se opor à intervenção norte-americana na guerra, a extração da borracha amazônica (juntamente com a produção e o armazenamento de estoques de outras matérias-primas no hemisfério ocidental) literalmente salvaria os Estados Unidos da catástrofe iminente. Abraçando o pan-americanismo como uma alternativa ao envolvimento nos conflitos do Velho Mundo, o America First dedicou significativa atenção ao comércio com a América Latina. Dominado por republicanos contrários ao New Deal, o America First tinha apenas cerca de 250 mil membros, concentrados principalmente no interior do país. Porém, através de grandes comícios, da distribuição copiosa de material impresso, do patrocínio de locutores de estações de rádio nacionais, da pesquisa e do fornecimento de informações para o Congresso, a organização tornou-se muito influente na defesa de uma posição anti-intervencionista nos Estados Unidos, forçando Roosevelt a ser mais contido em suas propostas legislativas. ${ }^{34}$ Por exemplo, o America First criticava os "alarmistas" que diziam que os japoneses poderiam debilitar a economia americana com um ataque às commodities estratégicas do Sudeste asiático: "Não precisamos ir à guerra por causa de borracha ou cobre; nossos rapazes não precisam lutar e morrer em Dong Dang [sic] ou Bangkok. O hemisfério ocidental é autossuficiente em matérias-primas" (Marshall, 1995, p.27-28). Ou, como esbravejou o senador Robert La Follette, num discurso no Congresso, em 24 de fevereiro de 1941:

se, a nossos fantásticos recursos, adicionarmos os de uma América Latina amiga, conseguiremos superar nossa maior deficiência: a de borracha - borracha que foi originalmente desenvolvida no hemisfério ocidental e que pode agora ser trazida de volta para satisfazer nossas necessidades... Com esses recursos fabulosos, com o poder humano e o poder das máquinas de transformá-los em bens para satisfazer a fome humana por sustento e sentido, podemos acabar com o paradoxo da pobreza em meio à abundância. Podemos erguer um farol para iluminar o modo de vida em liberdade para toda a humanidade. (citado em Doenecke, 1990, p.128)

Elogiando as missões exploratórias da borracha na América Latina organizadas pelo Departamento de Agricultura dos Estados Unidos e um acordo com o Brasil que autorizava o governo a comprar todo o excedente da borra- 
cha brasileira produzida para exportação, o America First se comprazia em afirmar que "em dez anos, a produção brasileira voltaria à sua antiga preeminência” (Doenecke, 1990, p.154, 173).

O entusiasmo com a Amazônia, forjado nos desdobramentos políticos do pan-americanismo e em meio à incerteza global, evoluiu a partir de vários tropos culturais dos Estados Unidos e ao mesmo tempo os evocou. O projeto hemisférico da borracha foi, inicialmente, alardeado como uma estratégia geopolítica para forjar laços interamericanos e diminuir a dependência dos Estados Unidos em relação aos mercados do Velho Mundo. Porém, a reabilitação do comércio amazônico propunha reorientações radicais para o capitalismo industrial norte-americano, refletia visões providencialistas de uma cornucópia edênica através da troca e do armazenamento de cultivos complementares, invocava uma renovação espiritual por meio da comunhão cultural e prometia ganhos materiais e regeneração política através da conquista da fronteira. ${ }^{35}$ Contudo, apesar de conjurarem a floresta tropical como arsenal, laboratório, fazenda ou templo, os defensores da modernização da Amazônia enfrentavam dificuldades para convencer os céticos compatriotas da sua indispensabilidade para a política econômica dos Estados Unidos. Seus detratores argumentavam que os plantations de borracha da América Latina, mesmo se bem-sucedidos, levariam, na melhor das hipóteses, pelo menos dez anos para produzir: dois anos para plantar sementes, criar mudas em viveiros, esperá-las brotar e transplantá-las; mais dois anos para começar uma plantação; outro cinco antes que a extração pudesse começar (Brandes, 1941, p.11). E, no curto prazo, com sua pequena produção, o comércio da borracha silvestre da Amazônia não conseguiria saciar o voraz apetite dos consumidores norte-americanos. Relatórios do U. S. Army and Navy Munitions Board e da U. S. Tariff Comission asseveraram, em 1940, que a borracha amazônica seria incapaz de substituir a oferta asiática em curto prazo, na hipótese de uma crise. ${ }^{36}$

De fato, os meros 500 mil dólares destinados pelo Congresso norte-americano em 1940 para campos de pesquisa de borracha e para o estabelecimento de estações experimentais no Brasil e em outros países do hemisfério ocidental refletiam a relativa fraqueza dessa posição nos círculos decisórios - particularmente em comparação com os 700 milhões de dólares gastos pelo governo dos Estados Unidos no desenvolvimento de borracha sintética durante a guerra. Por sua vez, os grandes manufatureiros norte-americanos da borracha, acomodados aos esquemas restritivos da Europa, relutavam em investir em plantations de borracha no hemisfério ocidental, especialmente depois do fracasso de Henry Ford na Amazônia. Como afirmou a companhia Goodyear: 
“o estabelecimento de plantations de borracha no hemisfério ocidental para satisfazer nossas necessidades de borracha dificilmente pode ser considerada uma solução prática". ${ }^{37}$ Plantations de borracha na Amazônia não seriam impossíveis, mas eram dispendiosas, e as companhias norte-americanas não estavam dispostas a correr o risco. ${ }^{38}$ Além disso, se o significado é algo produzido dentro de contextos simbólicos preexistentes (que variam de acordo com o grupo cultural), ${ }^{39}$ os norte-americanos se aferravam a imagens gastas da degeneração tropical. Em 1940, William La Varre, membro da Royal Geographical Society e da American Geographical Society, observou, a respeito da sua jornada nas florestas tropicais da América do Sul: "A selva não é amiga de ninguém. Alguns homens ficam loucos lá - loucos com a escuridão, loucos com o calor, loucos com quarenta dias de chuva, loucos consigo mesmos". ${ }^{40}$ No seu Let's See South America (1939), Anna Witherspoon se maravilhava com a "grande variedade e a abundância de vida animal e vegetal" nas florestas tropicais, mas reclamava que "o clima quente e a natureza induziam à preguiça", que os homens trabalhavam "apenas o suficiente para prover suas necessidades básicas. Eles são despreocupados e irresponsáveis”. ${ }^{41}$ (Numa pesquisa do final de 1940 feita pelo Office of Public Opinion, os entrevistados tiveram de escolher, entre dezenove adjetivos, aqueles que melhor descreviam todos os habitantes das Américas Central e do Sul: entre 40 e $50 \%$ escolheram "destemperados", "emocionais", "supersticiosos", "atrasados”, "preguiçosos", "ignorantes" e "suspeitos", enquanto apenas 5\% escolheram "eficientes") (Pike, 1998, p.291-292).

De fato, nenhuma das opções à excessiva dependência norte-americana da borracha crua asiática foi seguida com sucesso, antes de Pearl Harbor. Em junho de 1940, Roosevelt delegou à recém-criada Rubber Reserve Company (RCC) - agência governamental com orçamento de 140 milhões de dólares, subordinada à Reconstruction Finance Corporation - a missão de estocar borracha crua e, ao mesmo tempo, estabelecer uma indústria da borracha sintética. ${ }^{42}$ Porém, o medo de um crescimento exagerado, seguido de uma contração, assombrava autoridades do governo e líderes empresariais, deixando o país vulnerável na ocasião do ataque japonês. Com sua inclinação a favor da empresa privada e do corte de custos, a Rubber Reserve havia apostado pouco na borracha crua num mercado global cada vez mais competitivo, permitindo que o látex fosse rapidamente consumido por outros países e pela indústria privada nos Estados Unidos. Além disso, não conseguiu criar a base para uma indústria de produção em massa de borracha sintética. Roosevelt, fragilizado pelo sentimento isolacionista, pela oposição interna e pela própria indecisão, 
moveu tímidos esforços para armazenar estoques de borracha e de outras matérias-primas estratégicas; e a população norte-americana, ainda se recuperando da depressão econômica e cautelosa ante um novo envolvimento nos conflitos do Velho Mundo, não conseguiu se mobilizar para pressionar por alternativas. A integração vertical da produção e da manufatura de borracha exigia um grau de intervenção governamental que não era sustentável interna ou externamente, antes que o Japão tomasse o controle das colônias produtoras de borracha do Sudeste asiático. ${ }^{43}$ De fato, o fracasso do governo norteamericano em desenvolver a borracha sintética, encontrar fontes alternativas de borracha ou criar estoques emergenciais durante o período entre-guerras refletia, basicamente, as limitações de uma política pública que havia delegado a aquisição de materiais estratégicos à iniciativa privada, mas não tinha poder para obrigar as corporações a buscar ou desenvolver fontes alternativas de borracha crua ou sintética. ${ }^{44} \mathrm{~A}$ entrada dos Estados Unidos na guerra depois de Pearl Harbor acabou não apenas com as ilusões da "paz hemisférica", mas também com o impasse político em relação à dependência da borracha. Na medida em que o envolvimento do governo norte-americano na Amazônia se intensificava, o mesmo acontecia com os debates sobre a importância da região para o país.

\section{Salvem a Amazônia: o New Deal para}

\section{A FLORESTA DO BOARD OF ECONOMIC WARFARE}

Quando os japoneses tomaram o controle das colônias produtoras de borracha do Sudeste asiático em fevereiro de 1942, os Estados Unidos perderam o acesso a $97 \%$ de suas fontes tradicionais. Com um estoque governamental de apenas 570 mil toneladas de borracha crua - suficiente para menos de um ano - e uma indústria sintética embrionária, a nação se viu diante da possibilidade de falta de borracha para o exército e para outras demandas essenciais em janeiro de 1944 (e essa estimativa não levava em conta o uso de borracha em automóveis civis). O Rubber Survey Committee, criado por Roosevelt em agosto de 1942 para determinar o curso de ação apropriado para o governo, apoiou a rápida expansão do programa sintético, o racionamento de gasolina em todo o país, um limite nacional de velocidade de 35 milhas por hora (para prolongar a vida dos pneus dos automóveis) e a indicação de um Rubber Director para supervisionar as medidas (Tuttle, 1981, p.35-67). Mesmo priorizando os sintéticos, os atrasos para montar novas indústrias, assim 
como a indispensabilidade da borracha natural para pneus de caminhões e aviões, levaram o governo norte-americano a se envolver mais diretamente em projetos para aumentar a produção de borracha crua na América Latina. Tendo em vista o intervalo entre o plantio e a colheita, o cultivo da hevea no Brasil, até então favorecido pelo Departamento da Agricultura dos Estados Unidos e pelo regime Vargas, foi considerado impraticável para uso imediato em tempos de guerra, dando um estímulo inesperado ao comércio tradicional da borracha silvestre na Amazônia.

A historiografia brasileira da "batalha da borracha" enfatizou amplamente o contexto e o escopo do envolvimento dos Estados Unidos na Amazônia durante a guerra. ${ }^{45}$ Em acordos bilaterais assinados com o Brasil em Washington em março de 1942, os Estados Unidos criaram um fundo de cinco milhões de dólares para melhorar a qualidade da borracha produzida na Amazônia, e uma quantia similar para financiar um programa de saúde e saneamento nas áreas produtoras de borracha (McCann, 1974, p.267-268; Moura, 1980, p.167-168). O acordo previa a venda de todo o superávit exportável de borracha crua do Brasil para os Estados Unidos por um preço fixo até 31 de dezembro de 1946. Os Estados Unidos também se comprometeram a subsidiar a migração de dezenas de milhares de nordestinos para a Amazônia, para extrair borracha. Contudo, as controversas visões do comércio de borracha na Amazônia entre agentes do governo norte-americano, durante a guerra, não têm sido objeto de um exame sistemático, um exercício que pode historicizar como fatores econômicos e ideológicos informaram e dividiram as opiniões no hemisfério Norte sobre a floresta.

A maior capitalização do comércio da borracha na Amazônia não resolveu, para os agentes do governo dos Estados Unidos, o velho dilema dos seringalistas: a capacidade de ditar a velocidade da produção quando os seringueiros mantinham seu próprio ritmo de trabalho e padrão de vida. Os donos das terras na Amazônia tinham, tradicionalmente, obtido mais lucro de seus "fregueses" através de um sistema monopolista de vendas e endividamentos dos trabalhadores, e não pela produção propriamente dita de borracha. ${ }^{46}$ Os agentes do governo dos Estados Unidos, tentando maximizar a produção de látex para o esforço de guerra, tinham, claramente, prioridades diferentes, mas estavam divididos em relação à melhor estratégia para aumentar a quantidade de borracha produzida. John Hertz, Conselheiro Especial do Subsecretário de Guerra, afirmou que o preço baixo da borracha iria desencorajar os seringueiros a produzir látex e/ou induzir a extração de outros produtos da floresta: "é de se duvidar se ele estará disposto a assumir os riscos de trabalhar 
em selvas e florestas pela pequena porção... que eventualmente receberia por seu trabalho". ${ }^{47}$ Seus opositores, porém, reclamavam que preços altos levariam os comerciantes a estocar a mercadoria e seringueiros desleixados a desistir de trabalhar de vez, uma vez obtido um pequeno lucro. ${ }^{48}$ Como em outras políticas de obtenção de matéria-prima no hemisfério, os agentes do governo norte-americano debatiam se o maior perigo das políticas de bemestar nos acordos externos seria irritar os empregadores ou radicalizar os trabalhadores. ${ }^{49}$

Com a crise da borracha acirrando os ânimos nos Estados Unidos, a Amazônia se viu rapidamente no meio da disputa política. O conflito sobre a política de obtenção de borracha na Amazônia se originou, em sentido estrito, de uma superposição de competências, característica do estilo de governança de Roosevelt, que tentava manter uma improvável aliança entre liberais do Norte e conservadores sulistas que formavam sua base de poder no Partido Democrata. Desde junho de 1940, a Reconstruction Finance Corporation (RFC) tinha desfrutado de poderes expandidos por causa da guerra, o que lhe permitia criar corporações subsidiárias para defender o interesse nacional e para a aquisição de matérias-primas estratégicas. A Rubber Reserve, uma de suas subsidiárias, tinha sido autorizada a produzir, adquirir, transportar e negociar borracha e a tomar empréstimos da RFC. ${ }^{50}$ Após a invasão japonesa da Malásia, a RFC foi atacada na imprensa: atribuiu-se a culpa pelo agravamento da escassez de borracha a sua abordagem de obtenção orientada para os negócios privados e corte de custos, promovendo interesses corporativos, além de ter-se mostrado incapaz de tomar decisões. Por meio da Ordem Executiva 9128, de 13 de abril de 1942, Roosevelt investiu o Board of Economic Warfare (BEW, antes chamado de Economic Defense Board), dirigido pelo vice-presidente Henry Wallace, de completo controle sobre o direcionamento da produção e a obtenção de toda matéria-prima do exterior. De acordo com a Ordem Executiva, a Rubber Reserve não teria poder para delegar autoridade ou delimitar as responsabilidades de seus representantes e para decidir o uso de fundos de desenvolvimento sem ordem do BEW. ${ }^{51}$ Teoricamente, a Rubber Reserve serviria agora como a agência administrativa do governo para levar a cabo os planos formulados pelo BEW..$^{52}$

A repartição de competência sobre as políticas da borracha entre a RFC e o BEW, entre abril de 1942 e fevereiro de 1943, engendrou lutas internas na burocracia. Como o Departamento de Estado reclamava ao presidente, a Ordem Executiva de 13 de abril de 1942, conferindo novos poderes e funções ao BEW para a aquisição e o desenvolvimento de materiais estrangeiros, ia de 
encontro aos procedimentos existentes para negociações com governos estrangeiros - conduzidas pelo Departamento de Estado - e a função de gerência operacional, que foi assumida pela RFC. Usando de atrasos e de parcimônia, o presidente da RFC, Jesse Jones, retardou as ações e o escopo do programa de obtenção de matérias-primas do BEW (Blum, 1976, p.283). Em dezembro de 1942, frustrados com a RFC, executivos do BEW prestaram depoimento perante o Comitê do Sistema Financeiro e de Assuntos Monetários do Senado, atestando o fracasso de Jones em cumprir a instrução para estocar materiais estratégicos, incluindo o atraso no programa da borracha, sob sua responsabilidade, assim como a estagnação da coleta de borracha silvestre na América do Sul..$^{53}$ Milo Perkins, o diretor do BEW, que atribuía mais importância à rápida aquisição de borracha e da boa vontade internacional que ao preço pago por isso, afirmou: "Em minha opinião, tendo em vista o preço da borracha, deve-se ignorá-lo completamente e conseguir cada quilo que pudermos, a despeito dos custos". ${ }^{54}$

Mas a dura disputa sobre a política de obtenção de borracha derivava ainda da competição entre as visões de diferentes facções do Partido Democrata - que refletiam a aguda divisão ideológica dentro do próprio partido (Schapsmeier, 1971, p.57). Com o início da guerra, Roosevelt havia proclamado o fim do liberalismo do New Deal e feito um apelo à unidade nacional. Pouco depois de Pearl Harbor, ele observou: "O slogan era 'Vencer a guerra antes de pensar muito nos planos para o pós-guerra”" (Walker, 1976, p.93). Mas, se Roosevelt não usaria a guerra para promover reformas, ele não abandonaria de todo suas bandeiras, aprovando a posição que o vice-presidente assumira, de um audacioso porta-voz para testar a reação de plateias nacionais e internacionais a propostas políticas - para o tempo de guerra e para o pós-guerra - mais ousadas do que o presidente poderia se arriscar a defender. Para Wallace, assim como para outros adeptos do New Deal, a guerra trazia várias expectativas sobre o pós-guerra, tornando difícil traçar distinções claras entre as preocupações estratégicas e o planejamento do pós-guerra. Ele afirmou: "estamos delineando o mundo do pós-guerra agora mesmo". ${ }^{55}$ Temendo que o papel preponderante das grandes empresas durante a guerra permitisse que se firmassem práticas de negócios conservadoras, que os programas de bem-estar social nos Estados Unidos sofressem ataques e que erros na política externa norte-americana pudessem contribuir para conflitos internacionais, Wallace defendeu o apoio dos Estados Unidos à industrialização de países mais pobres e a criação de agências internacionais para fazer empréstimos de longo prazo a "nações industrialmente atrasadas". ${ }^{56}$ Ademais, o BEW 
pôs em prática políticas do New Deal, que enfatizavam a importância de pagar salários mais altos e promover o bem-estar social dos produtores de matérias-primas na América Latina, em meio a um desenvolvimento econômico em bases mais amplas.

A política em relação à borracha se tornou, durante a guerra, um campo de batalha para os ideais do vice-presidente de garantir estabilidade econômica de longo prazo e justiça social, tanto na América Latina como nos Estados Unidos. Mesmo tendo o BEW reconhecido os numerosos obstáculos para aumentar a produção na América Latina - a falta de mão de obra, péssimas condições sanitárias, suprimentos inadequados e transporte ruim -, Wallace considerava a "aquisição imediata" de borracha silvestre do Vale do Amazonas um dos mais importantes projetos do BEW. ${ }^{57}$ Atacando os "sistemas de cadernetas" e qualquer outra forma de provisão de mão de obra escravizada por dívidas - que atavam o trabalho a vínculos de servidão, restringindo a mobilidade dos seringueiros na Amazônia -, o BEW prometeu evitar "uma repetição dos escândalos do último ciclo da borracha, mesmo numa escala reduzida" ${ }^{58}$ Os agentes do BEW insistiram na oferta de preços mais altos pela borracha, melhoramento da condição social dos seringueiros e apoio ao desenvolvimento da infraestrutura da Amazônia como políticas essenciais para o sucesso do programa. ${ }^{59} \mathrm{O}$ Office of Inter-American Affairs (OIAA) estava igualmente comprometido com a implantação de programas de saúde e nutrição na América Latina, a fim de aumentar a produtividade do trabalho e conquistar corações e mentes, assim como preparar o terreno para o desenvolvimento da economia e do comércio no pós-guerra e para a expansão do mercado para firmas norte-americanas (Wallace e Rockefeller jogavam tênis regularmente e o vice-presidente costumava aproveitar a ocasião para doutrinar Rockefeller sobre o destino dos pobres na América Latina: "Eu disse que a solução para o problema requeria um novo espírito missionário, um espírito que tenha apelo junto a religiosos e também a empresários"). ${ }^{60}$ Assim, o BEW alertou que a produção de borracha não aumentaria, a não ser que o governo norte-americano tomasse medidas vigorosas para interromper o rápido aumento do custo de vida para os trabalhadores, melhorando as condições econômicas e aumentando a produção agrícola e o fornecimento de suprimentos na Amazônia. O BEW conduziu numerosos estudos para determinar a quantidade de borracha produzida por seringueiro, o pagamento por quilo para cada seringueiro, o preço cobrado pelos suprimentos, e o lucro, se algum, que os seringueiros acumulariam ao final da temporada; a agência também comparou esses valores com o nível salarial no Nordeste brasileiro e em outras 
ocupações na própria Amazônia. ${ }^{61}$ Projetando um cenário ideal, o BEW havia preparado um plano de incentivo à produção, que previa que os seringueiros em cada região teriam uma cota média a cumprir e seriam recompensados, em dinheiro, em bens ou em prêmios, diretamente pela Rubber Reserve, pela produção além dessa cota. Agentes do Board of Economic Warfare esperavam ainda que a competição entre seringalistas levasse à melhora das condições dos seringueiros. ${ }^{62}$

Os agentes do BEW tinham uma visão profundamente crítica da influência das corporações norte-americanas nas operações da Rubber Reserve na região da Amazônia, que privilegiavam empresas privadas (na sua maioria, brasileiras), limitando o envolvimento do governo. Na América do Sul, como perceberam os agentes do BEW, os "poucos e seletos homens" empregados pela Reconstruction Finance Corporation eram cidadãos norte-americanos pessoal e financeiramente envolvidos com as indústrias produtoras. ${ }^{63} \mathrm{~A}$ lista de suspeitos incluía: J. W. Brickell, vice-presidente executivo da Rubber Reserve, que, por muitos anos, havia supervisionado as operações da United States Rubber Company na Ásia; R. B. Bogardus, vice-presidente da Rubber, oriundo da Goodyear Tire and Rubber Company; William Clayton, o secretário-assistente de comércio e diretor do programa de compras exteriores da RFC, presidente da Anderson-Clayton, agência de corretagem de algodão, dona de máquinas compressoras de algodão, máquinas descaroçadoras e depósitos no Brasil e em outros países sul-americanos; e Maurice McAshan, o principal representante da RFC e vice-presidente da Rubber no Brasil, e genro de Clayton. ${ }^{64}$ Ao retornar da Amazônia brasileira, em agosto de 1942, Paul R. Hays, chefe da Seção de Desenvolvimento da Divisão da Borracha do BEW, fez duras críticas ao mau planejamento e à organização do programa da borracha, cujos responsáveis negligenciavam o problema da comida e dos suprimentos para os seringueiros, mostrando-se incapazes de protegê-los. Desafiando a propalada imagem de eficiência dos agentes da Rubber Development, Hays declarou:

Não há razão para acreditar que, apenas porque um homem teve sucesso como subordinado ao cuidar de um empreendimento de interesse dos Estados Unidos de escopo comercial limitado, ele vá ser capaz de organizar os enormes problemas de suprimento, mão de obra, transporte e produção na Amazônia. A ênfase em experiência comercial, assim como a ênfase em experiência brasileira, está limitando a disponibilidade de pessoal e produzindo empregos altamente frustrantes. ${ }^{65}$ 
Nesse sentido, o BEW alertou a Rubber Reserve para que não se opusesse a um salário mínimo e a uma legislação social, alegando que isso aumentaria o preço da borracha, mas que usasse os fundos de desenvolvimento para ajudar os produtores a pagar esses salários e cumprir os demais requerimentos. Além disso, para proteger os direitos dos seringueiros, o BEW exigiu um contrato-padrão, escrito, "protegendo adequadamente o trabalhador contra a exploração". ${ }^{66}$

De fato, os agentes do BEW apoiaram, em toda a América Latina, a implantação de modelos de contratos obrigando governos e empresários a garantir salários justos (não menos que aqueles pagos em operações comparáveis do contratador em outras áreas do país em questão ou não menos do que aqueles pagos por outras pessoas por um trabalho comparável), a obedecer às leis trabalhistas locais, a manter padrões sanitários, suprimento de comida e abrigo para os trabalhadores empregados na política de obtenção da matériaprima para a guerra. ${ }^{67} \mathrm{Na}$ primavera de 1943 , havia mais de cem contratos com essas cláusulas. Várias exigências do BEW seriam incluídas em contratos de trabalho oficiais para seringueiros que foram instituídos (mas raramente adotados) pelo regime Vargas. ${ }^{68}$ Ao OIAA foi confiada a missão específica de prover assistência em programas de saúde e saneamento na Amazônia, sob as cláusulas trabalhistas dos contratos do programa da borracha. ${ }^{69}$

O BEW defendia a importância de políticas sociais na América Latina empregando o discurso da segurança nacional. Deixando de lado as considerações humanitárias, condições ruins de trabalho se traduziam num material de guerra de pior qualidade. ${ }^{70} \mathrm{~A}$ produção de borracha, segundo o BEW, estava diretamente ligada à redução da taxa de mortalidade e ao aumento das "horas-homem anuais de trabalho efetivo", através do controle da malária e do fornecimento adequado de comida. ${ }^{71}$ Como política externa, medidas protecionistas nos contratos de obtenção de matérias-primas conquistariam corações e mentes dos produtores rurais da América Latina, ajudando-os a "ler e a escrever, melhorar suas técnicas agrícolas e aprender noções básicas de mecânica". ${ }^{72}$ Além disso, o cumprimento de padrões mínimos de bem-estar pelo governo norte-americano ajudaria a combater a propaganda nazista que buscava desacreditar o programa de matérias-primas como uma forma de "imperialismo ianque" que explorava os trabalhadores latino-americanos. ${ }^{73}$ Ajudaria ainda a controlar a onda de nacionalismo econômico na América Latina e a fortalecer a posição dos Estados Unidos entre os setores mais progressistas e liberais (Schapsmeier, 1971, p.57-58; Blum, 1973, p.151). Para evitar acusações de intervencionismo, o BEW insistiu em que nenhuma das 
cláusulas dos contratos visava aplicar a legislação trabalhista dos Estados Unidos em países estrangeiros, mas seguir os padrões locais do país de origem. ${ }^{74}$ Os Estados Unidos não tomariam para si a responsabilidade de impor o respeito às leis trabalhistas locais, a não ser na medida em que isso promovesse o propósito da legislação local. ${ }^{75}$

Não obstante, os agentes do BEW afirmaram que, no coração de suas iniciativas de política externa, havia uma determinação histórica do governo dos Estados Unidos em promover condições de trabalho justas em outros países. ${ }^{76}$ Leonard H. Heller, o chefe da Divisão da Borracha no Board of Economic Warfare, foi bastante enfático sobre qual deveria ser a posição dos Estados Unidos na Amazônia: “Acreditamos que uma agência do governo não deveria aceitar, no Brasil, a escravidão por dívidas, o que seria inconstitucional nos Estados Unidos". ${ }^{77}$ Os agentes do BEW falavam, com orgulho, da sua missão: "É a primeira vez na história que um país, ao negociar produtos com outro, deu garantias expressas contra a exploração do trabalho; e reconheceu, de forma franca e realista, que homens e mulheres trabalhadores que recebem um salário justo, cumprem uma jornada razoável e trabalham e vivem em condições decentes de saúde e saneamento, produzem mais e melhores produtos que aqueles em outra situação". ${ }^{78}$

A visão de Wallace de um New Deal global, que chegaria ao "homem comum" até mesmo no coração da Amazônia, foi abraçada por Charles Wilson, em seu Trees and Test Tubes (1943). Na sua história mundial da indústria da borracha, Wilson comparou o bem-estar dos trabalhadores dessa indústria nos Estados Unidos com o de seringueiros nos trópicos. Ele observou que, enquanto os trabalhadores das fábricas de pneus de Akron, no Ohio, recebiam bons salários,

seus empregos eram, havia muito, desesperadamente ameaçados pela servidão, pela escravidão por dívidas e pela amarga pobreza de centenas de milhares de trabalhadores desconhecidos, de pele escura, do outro lado da Terra - aqueles outros homens de borracha, cujo suor, esforço e sofrimento tornaram possível a maior parte do movimento indispensável à vida e ao comércio nos Estados Unidos, assim como a existência de pneus e trabalhadores nas fábricas de Akron.

Consternado, Wilson se perguntou: "Como, num mundo do futuro, poderemos melhorar a desgraçada condição dos cerca de $80 \%$ dos essenciais produtores de borracha, que têm recebido menos que 25 centavos por dia?". Mais especificamente, ele argumentava: 
Teremos de reconhecer o direito do trabalhador rural que produz borracha crua de ganhar salários compatíveis com aqueles dos que fazem a manufatura final da borracha. $\mathrm{O}$ futuro da borracha exige uma fraternidade internacional do trabalho. Ultrapassando os limites nacionais e territoriais, exige justiça econômi$\mathrm{ca}$ - a necessidade de uma justiça internacional do amanhã.

Wilson defendia que o apoio norte-americano para a criação de fazendas familiares nas Américas distinguiria sua política externa das práticas coloniais europeias que empobreceram e exploraram trabalhadores estrangeiros:

As terras de extração de borracha do hemisfério ocidental podem ser, e serão, terras de homens livres e da iniciativa privada; o crescimento da borracha pode e irá se incorporar a uma nova e melhor ordem da agricultura e do comércio no hemisfério - uma ordem livre das anarquias dos cartéis internacionais e de outros artifícios gerados pelo lucro exorbitante de uns poucos escolhidos e frequentemente ausentes, tendo como preço a subjugação econômica e política de inúmeros povos tropicais. ${ }^{79}$

Para Wallace e outros progressistas, os desequilíbrios comerciais, remanescentes do isolacionismo que se seguiu à Primeira Guerra Mundial, desestabilizariam a economia mundial e tornariam outra guerra "inevitável". Com o avanço do Brasil e de outros países latino-americanos na produção de borracha natural (em cuja eficiência a ser alcançada em alguns anos Wallace apostava, graças a experimentos com enxertos e ao uso de variedades altamente produtivas de hevea), o vice-presidente escreveu, preocupado, em seu diário: "uma barreira tarifária para proteger uma indústria nascente da borracha sintética neste país não só forçaria nossos consumidores a pagar mais caro, mas representaria um duro golpe para esses países e sua fé em nossa amizade". Assim, quando Jesse Jones rejeitou a sugestão de Wallace de que a borracha dos seringais na América Latina poderia ser produzida, no futuro, por até dez centavos a libra, o vice-presidente contra-atacou com outra justificativa para promover a produção de borracha crua no hemisfério ocidental: "Eu disse a ele que, se esperávamos vender alguma coisa para o resto do mundo depois da guerra, teríamos de descobrir o que poderíamos aceitar do resto mundo. E a borracha é uma dessas coisas". Convencido de que a indústria do petróleo, que manufaturava o butadieno (um dos copolímeros da borracha sintética), tinha promovido cinicamente a borracha sintética como necessária à segurança durante a guerra, Wallace fulminou: "é evidente que o pessoal da indústria do petróleo, interessado na criação de uma indústria que lhe seria 
lucrativa, sacrificou o bem-estar nacional à própria cupidez ou ignorância”. Wallace afirmou que

uma sábia política de Estado para a borracha, que olhe para o futuro, levará em consideração todos os fatores que listei - o baixo custo para motoristas, a certeza do suprimento, a promoção da segurança através de laços de amizade com nossos vizinhos neste hemisfério e relações internacionais mais amplas que vão ajudar a assegurar um mundo pacífico. ${ }^{80}$

Nesse sentido, Wallace havia reinventado um papel redentor para a generosidade tropical: a borracha amazônica iria resgatar a cidadania norte-americana das garras monopolistas do capitalismo industrial. (Ainda assim, reconhecendo que a principal fonte de borracha durante a guerra seria a sintética, Wallace apoiava controles governamentais para combater a fixação de preços e os trustes corporativos e para assegurar maior flexibilidade na acomodação dos interesses econômicos e políticos dos produtores latino-americanos que, acreditava, a indústria privada iria desprezar.) (Schapsmeier, 1971, p.59).

A visão do BEW para a Amazônia refletia o compromisso de Wallace com uma agenda progressista global, voltada para restringir o capitalismo corporativo e melhorar a condição social dos pobres na América Latina. Refletindo uma mistura do idealismo cristão e do internacionalismo de Woodrow Wilson, Wallace anteviu uma era em que a paz e a abundância abençoariam todos os povos (Schapsmeier, 1971, p.55; Walker, 1976, p.86). No projeto do BEW, a assistência financeira, a orientação científica e a supervisão política providas pelo governo dos Estados Unidos modernizariam e moralizariam a sociedade amazônica, resgatando um mercado local que, por muito tempo, permanecera prisioneiro de inescrupulosas empresas privadas, tanto domésticas como transnacionais. Wallace pensava que os trabalhadores amazônicos mereciam um padrão de vida mais elevado e uma existência mais digna. Nem o caráter nacional, nem o miasma tropical impediam o aumento da produção de borracha na Amazônia, mas sim a exploração dos seringueiros por seringalistas que, por sua vez, se viam numa posição de desvantagem no comércio global, dominado por trustes corporativos.

O apoio de Wallace à ajuda governamental dos Estados Unidos a nações em desenvolvimento prenunciava a agenda do pós-guerra de agências como a U. S. Agency for International Development. E sua defesa dos direitos dos trabalhadores na Amazônia ecoava as lutas contemporâneas dos ativistas dos direitos humanos e trabalhistas. Porém, no que em muito se assemelhava a 
Woodrow Wilson, Wallace tinha uma visão etnocêntrica ao buscar reconstruir as nações latino-americanas nos moldes progressistas dos Estados Unidos. Wallace tinha também uma desconfiança inata da capacidade dos países latino-americanos de exercer um governo competente (acusações similares foram feitas ao OIAA de Rockefeller, que promoveu como uma missão civilizadora a americanização da saúde, da agricultura e da vida cultural dos países latino-americanos, alardeando o desenvolvimento econômico e a expansão do poder de compra estrangeiro sem redistribuição da riqueza ou caridade). ${ }^{81}$ Em fevereiro de 1942, por exemplo, um mês antes da assinatura dos Acordos de Washington, o BEW e o OIAA propuseram um ousado plano para uma operação liderada pelos Estados Unidos na Amazônia, para melhorar o transporte, o saneamento e a habitação ${ }^{82}$ Seria criada uma Corporação de Desenvolvimento da Amazônia e metade de suas ações seria de propriedade conjunta dos governos do Brasil e dos Estados Unidos, com um brasileiro na presidência e um norte-americano como diretor-geral. A proposta foi atacada pelos representantes brasileiros, que discordaram da indicação de um agente norte-americano para o cargo de diretor-geral de uma corporação cuja metade pertencia ao governo brasileiro. ${ }^{83}$ Não obstante, o BEW faria insistentes pedidos por um maior compromisso do governo dos Estados Unidos com salários mais altos, condições de trabalho mais justas, habitação e assistência médica adequadas e estoques de comida na Amazônia, condenando os fracassos do regime Vargas na proteção do bem-estar dos seringueiros, como exigia o contrato oficial de trabalho, assim como a deferência dos agentes da Rubber Reserve para com as autoridades brasileiras nesses assuntos. ${ }^{84}$

Mesmo que a visão de Wallace para o desenvolvimento amazônico tenha vindo, indubitavelmente, de programas do New Deal, como a Tennessee Valley Authority, que buscavam combater o desequilíbrio regional e a pobreza rural, ela também se conformava ideologicamente a certa visão imperial, em que as colônias eram enxergadas como laboratórios da modernidade, onde cientistas, técnicos, educadores e nutricionistas poderiam realizar experimentos de engenharia social, supostamente para melhorar a condição dos povos mais "primitivos" ${ }^{85}$ Embora os agentes do BEW reconhecessem claramente a miríade de desafios econômicos, epidemiológicos e de infraestrutura que dificultavam uma reforma total da Amazônia, acreditavam na missão transformadora dos tecnocratas e servidores públicos norte-americanos. Dentro de uma longa tradição, o projeto do BEW reflete a tendência de estrangeiros verem a Amazônia como tábula rasa. Os internacionalistas do New Deal subestimaram não apenas a capacidade de o comércio de borracha amazônico re- 
sistir à arregimentação aos princípios de mercados e à supervisão governamental, mas também a feroz oposição dos conservadores nos Estados Unidos a uma política externa que ameaçava seus interesses econômicos e suas bases ideológicas. ${ }^{86}$

\section{A Rubber DeVelopment Corporation (RDC) E O “CORAÇÃo DAS treVAs” Amazônico}

Hostis a um maior estatismo nos Estados Unidos, mesmo em tempo de guerra (para não mencionar períodos de normalidade), os conservadores resistiram às ideias de Wallace sobre a ajuda econômica dos Estados Unidos e outras políticas reformistas que buscavam melhorar as condições sociais dos pobres na América Latina (Hoffman, 1992, p.67). Ao resumir o desdém corporativo pela agenda de Wallace, W. P. Witherow, presidente da Associação Nacional de Manufatureiros, declarou que "não estava lutando por meio litro de leite para cada hotentote, ou para criar uma Tennessee Valley Authority no Danúbio, ou pela proteção governamental para libertar a Utopia" (citado em Walker, 1976, p.91). O Chicago Tribune censurou "o místico Mr. Wallace", que "se dedicava a sonhos que deveriam atrair mais ceticismo que admiração", enquanto outros críticos denunciavam os esforços para "estender o New Deal por toda a Terra” (Blum, 1976, p.284-285). E Martin Dies, um deputado do Partido Democrata do Texas e presidente do Comitê de Atividades NãoAmericanas, distribuiu uma nota à imprensa declarando que vários altos funcionários do governo no BEW eram filiados ao Partido Comunista (Schapsmeier, 1971, p.52). Mas um dos mais ferrenhos críticos de Wallace era o democrata texano Jesse Jones, que presidira a RFC desde sua criação em 1932 e também fora indicado secretário do comércio em 1940, para atender aos democratas conservadores, insatisfeitos com a escolha de Wallace para vicepresidente. Jones, um poderoso empresário de Houston que tinha feito fortuna na indústria madeireira, no mercado imobiliário, na construção civil e no setor financeiro, defendia os interesses do empresariado, o conservadorismo fiscal e baixos preços das commodities. Como boa parte da opinião pública norte-americana, ele abominava a possibilidade de um New Deal na América Latina. Em suas memórias publicadas no pós-guerra, Jones atacou Wallace e seus colegas no BEW por "prejudicar o esforço de guerra" em seu "afã de jogar dinheiro fora para propósitos ruins", observando que o tino empresarial 
de seus associados tinha poupado o dinheiro dos contribuintes e salvara o programa da borracha de um escândalo nacional (Jones, 1951, p.489).

Nas políticas de obtenção ${ }^{\mathrm{b}}$ de matéria-prima, a RFC defendia uma relação de trabalho próxima com o capital estrangeiro e multinacional que, segundo os conservadores, tinha a experiência empresarial e as habilidades técnicas necessárias. ${ }^{87}$ Diferentemente dos defensores do "governo grande" no BEW com seus projetos para "americanizar a Amazônia", os agentes da Rubber Reserve insistiam em que o maior suprimento de borracha da Amazônia brasileira poderia ser obtido, no menor tempo possível, entregando a responsabilidade primária aos brasileiros e limitando o envolvimento de norte-americanos no programa da borracha à assistência técnica e às relações com os negociantes locais e os seringalistas. A assistência norte-americana na Amazônia deveria evitar a "interferência desnecessária nos hábitos e costumes do povo", incluindo tentativas de reformas sociais, "exceto quando tais reformas tiverem um impacto direto na produtividade do trabalho". Diziam também que os seringueiros não deveriam ganhar "muito dinheiro, a ponto de perder o interesse em continuar produzindo" ${ }^{88}$ Desprezando relatórios do BEW sobre as deploráveis condições sociais nos tributários remotos do Amazonas, Jones afirmaria, mais tarde: "nosso trabalho era produzir borracha", e, além disso, "as condições sociais em muitas partes dos Estados Unidos eram deploráveis, então não era surpreendente que o fossem na Amazônia" (Jones, 1951, p.425).

Os opositores das políticas para obtenção de matéria-prima do BEW também expressavam sua posição nos termos da segurança nacional. O respeito aos sistemas locais de negócios e às práticas culturais seria essencial para assegurar a produção e ganhar a boa vontade e o respeito das populações latino-americanas. ${ }^{89}$ Cláusulas impondo direitos sociais aumentariam o custo do trabalho ou encorajariam a vagabundagem, $e$ "dificilmente o papel das agências do governo dos Estados Unidos seria tornar a situação mais complicada para os patrões" ${ }^{90}$ Ademais, políticas norte-americanas que promovessem reformas socioeconômicas no comércio da borracha violavam a soberania brasileira e poderiam gerar atritos com um aliado central em tempo de guerra. ${ }^{91}$ Clayton, o secretário-assistente de comércio, declarou que, dado o "vigor" com que o Brasil "defende diligentemente suas prerrogativas nacionais", os apelos do BEW para que o Brasil entregasse aos Estados Unidos o controle da imigração e dos problemas de transporte na Amazônia eram ingênuos e perigosos: "afinal, o Brasil é uma nação soberana, e o governo dos Estados Unidos pode fazer no Brasil apenas o que o governo brasileiro nos deixar fazer e nada mais". ${ }^{92}$ Dadas as ansiedades geopolíticas das autoridades brasileiras na Ama- 
zônia, a Rubber Reserve condenou, particularmente, políticas que poderiam levantar suspeitas de uma "invasão americana" da Amazônia, incluindo a contratação de funcionários sem uma "consideração cuidadosa" de seu caráter e habilidade para representar apropriadamente uma empresa do governo norte-americano, especialmente em regiões distantes e sem a ajuda da embaixada ou dos homens mais importantes da Rubber Reserve..$^{93}$

A apaixonada defesa da soberania brasileira pelos conservadores era bastante arbitrária, considerando-se o substancial ingresso de capital norte-americano na região amazônica durante a guerra. Ademais, a defesa do relativismo cultural, vinda de tendências pró-empresariais e de pressões da diplomacia brasileira, e não de uma sensibilidade antropológica, serviu para evitar a questão fundamental do papel do governo norte-americano na promoção de condições de trabalho mais justas na América Latina. ${ }^{94}$ A oposição à legislação social na Amazônia revelava ainda o oportunismo político dos conservadores, que vilipendiavam políticas estatistas mesmo enquanto as corporações norteamericanas faziam fila para colher, no pós-guerra, lucros inesperados advindos do investimento maciço do governo na indústria sintética da borracha. ${ }^{95}$ De fato, as indústrias petrolífera, química e da borracha foram agentes fundamentais na promoção e no desenvolvimento da indústria sintética durante a guerra. Como a maioria das agências do período da guerra, o escritório do Rubber Director (criado a partir da recomendação do Rubber Survey Committee, em setembro de 1942, para supervisionar as medidas) recrutava seu pessoal das indústrias envolvidas, que defendiam o desenvolvimento de sintéticos pelo governo, em relação à promoção da borracha crua no hemisfério. ${ }^{96}$

Contudo, o repúdio ao internacionalismo do New Deal na Amazônia refletia também um cinismo mais profundamente assentado sobre a possibilidade de a assistência do governo dos Estados Unidos elevar o nível social dos trabalhadores na floresta. Em suas memórias, escritas no pós-guerra, Jesse Jones condenou Henry Wallace e seus "colegas reformadores sociais" que acreditavam que uma melhora nas condições de vida na Amazônia levaria a um aumento da produção de borracha. Ridicularizando a suposta sugestão de Wallace de que fornecer 350 mil toneladas de gêneros alimentícios básicos para os pobres da Amazônia rural (incluindo farinha enriquecida com vitaminas) tornaria os trabalhadores do programa da borracha mais produtivos, Jones notou, com sarcasmo: se a comida fosse dada de graça, os Estados Unidos obteriam menos borracha porque "as pessoas aqui, como a maioria das pessoas em todo o mundo, só trabalham porque querem comer. Se fossem alimentados de graça, muitos deles sequer trabalhariam e, portanto, haveria 
pouca ou nenhuma borracha." Jones atacou o BEW, declarando (falsamente) que suas cláusulas trabalhistas levariam os produtores latino-americanos a pagar a seus empregados salários com poder de compra equivalente ao da América do Norte, e a conceder "benefícios sociais" que, além de violar a soberania de outras nações e contrariar os patrões, teriam interferido "com os costumes referentes à alimentação, à moradia, à higiene e ao trabalho dos seus povos". Para dar suporte à sua argumentação, Jones escolheu o que provavelmente acreditava ser a mais ridícula das propostas de Wallace: a ideia de que "este seria um mundo mais feliz se ensinássemos aos índios nas selvas da Amazônia a cultivar vegetais à maneira da América do Norte”. Para Wallace, na realidade, os índios, "inocentes, estavam satisfeitos com uma dieta baseada em farinha de milho e feijão mexicano [sic]" (Jones, 1951, p.422-423, 491).c Em termos mais ásperos, Harold Gustin, técnico em borracha, expressara um pessimismo semelhante em relação aos seringueiros num diário que mantinha enquanto percorria os tributários do Baixo Amazonas:

Se até mesmo o estímulo de uma guerra naquele que, gostamos de acreditar, é o mais avançado país do mundo não incentiva seu povo a se esforçar ao máximo ou mesmo medianamente, que diabos se pode fazer para essas pessoas, mal pagas, mal alimentadas, doentes, ignorantes e, em geral, não-privilegiadas, produzirem além do absolutamente essencial para o que consideram uma vida satisfatoriamente confortável? ${ }^{97}$

Como vários acadêmicos têm argumentado, a autorrepresentação do poder colonial europeu e norte-americano se baseava, em parte, numa demarcação simplificada dos povos e das paisagens das regiões tropicais. A "tropicalidade" servia, de várias formas, a um contraste com a formação da identidade europeia e norte-americana, baseada na ideia de que esses eram lugares de temperança, racionalidade e frugalidade. ${ }^{98} \mathrm{Ou}$, como observa David Harvey, "denegrir os lugares dos outros é uma forma de afirmar a viabilidade e o poder incipiente de si mesmo" (Harvey, 1996, p.322). Culpando os seringueiros por sua pobreza, e não a exploração socioeconômica da região, que se inseria numa divisão internacional do trabalho, Jones revelou uma visão cínica (e cíclica) dos trabalhadores rurais amazônicos como peões ignorantes e preguiçosos, destinados à marginalidade social e dela merecedores. Mais que uma compreensão deficiente da Amazônia - atribuindo um papel central à farinha de milho e ao feijão numa dieta enriquecida pela mandioca - a posição política de Jones advinha de percepções culturais da floresta tropical como um lugar 
de debilitação física e decadência moral, e replicava tais percepções. Em Brazil: Bulwark of Inter-American relations (1945), Henry Albert Phillips defendeu que o fracasso do Brasil em criar plantations de borracha "reflete e revela algo basilar, localizado nas profundezas da essência do caráter brasileiro e de sua conduta como um todo", que ele resumia assim: "Os brasileiros não são realistas, e nunca o serão, num grau similar ao que os anglo-saxões podem ser e frequentemente são". E, ecoando outros lugares-comuns colonialistas sobre a incapacidade dos nativos para administrar os recursos naturais, ele exaltou a operação britânica que contrabandeou as sementes da borracha da Amazônia, sem a qual "a Era do Automóvel se atrasaria indefinidamente". 99

Jones e Wallace foram internacionalistas, em seus esforços para difundir os ideais norte-americanos - apoiando o livre-comércio e um sistema internacional integrado. Contudo, suas visões da Amazônia divergiam significativamente. Enquanto Wallace buscava apagar um legado de injustiças passadas na Amazônia, com a promessa de libertação futura, Jones ridicularizou os esforços para atribuir à região e a seus povos tamanha relevância histórica. Enquanto o paternalismo de Wallace enfatizava a redenção amazônica através de um esforço liderado pelos Estados Unidos, Jones desprezava a população nativa, que considerava impermeável ou hostil a mudanças.

O conflito entre conservadores e progressistas sobre as políticas para obtenção de matéria-prima na Amazônia atingiu um momento crítico ao longo de 1943. Em fevereiro, William Jeffers, Rubber Director, restaurou a jurisdição exclusiva da RFC sobre a obtenção e a produção de borracha natural em todos os países estrangeiros. [Nesse momento, o nome da agência foi oficialmente modificado, passando de Rubber Reserve para Rubber Development Corporation. $]^{100} \mathrm{O}$ Board of Economic Warfare foi oficialmente excluído de qualquer processo decisório relativo à produção e à obtenção de borracha natural. ${ }^{101}$ Em 15 de julho de 1943, Roosevelt aboliu o BEW e transferiu suas funções e seu pessoal para uma nova agência, o Office of Economic Warfare, comandado por Leo Crowley, um conservador amigo de Jones (Schapsmeier, 1971, p.70-71). Este continuou a chefiar a RFC, onde, como banqueiro-chefe da administração, controlava um vasto império de indústrias estatais. Enquanto isso, Wallace se tornara um estorvo, em razão da guinada para a direita do país, refletida nas vitórias dos republicanos nas eleições parlamentares de 1942. Assim, Roosevelt anunciou que Wallace não seria seu companheiro de chapa na eleição de 1944. A voz do progressismo do New Deal, nos Estados Unidos e na cooperação econômica inter-americana, foi silenciada, e 
Wallace foi privado das responsabilidades políticas com as quais esperava moldar a paz do pós-guerra (Gellman, 1979, p.169).

A indústria sintética norte-americana do período da guerra, um produto do esforço conjunto do Estado, da indústria, de cientistas e de universidades, exigiu um investimento de 700 milhões de dólares, inteiramente custeado pelo governo. Quinze fábricas, operadas por corporações privadas que eram ressarcidas dos custos e remuneradas pela administração, estavam funcionando já em fins de novembro de 1943. Em 1944, a produção de borracha sintética ultrapassou 773 mil toneladas e, ao final da guerra, as fábricas operavam com uma capacidade anual de 830.780 toneladas. Antes da guerra, os Estados Unidos eram o maior importador de borracha crua do mundo, porém, ao seu final, tornaram-se o maior exportador de borracha. Enquanto em 1942, 96\% da borracha consumida nos Estados Unidos era natural e 4\% sintética, em 1945 esses números eram $15 \%$ e $85 \%$, respectivamente. O sucesso do programa sintético nos Estados Unidos fez surgir uma nova e florescente indústria e elevou o status de cientistas cuja "metodologia objetiva" foi considerada crítica para as decisões políticas e para a guerra. Resultou também na perda de importância do comércio hemisférico de borracha crua. ${ }^{102} \mathrm{Na}$ Amazônia, a Rubber Development Corporation reduziu a escala de suas operações a partir de julho de 1943, sob a justificativa de que as despesas eram altas, os fornecedores locais se opunham à regulamentação estatal do comércio da borracha e a produção de látex era desapontadora. O comércio de borracha na Amazônia, outrora visto como antídoto para a dependência norte-americana da borracha, alicerce da cooperação interamericana ou baluarte contra a concentração industrial, acabou se tornando um epítome da degeneração tropical. Retornando de uma viagem de um mês à Amazônia em setembro de 1943, W. N. Walmsley, do Departamento de Estado, fez uma crítica devastadora ao comércio da borracha: "Não há, em lugar algum, um retrato mais aterrador do que, em países mais progressistas, chamamos de corrupção e exploração". ${ }^{103}$

\section{Conclusão}

Sobre o vale do rio Amazonas, Earl Park Hanson observou, em 1944: “é provável que nos últimos dois anos sua bacia tenha sido mais substancialmente explorada e mais conhecimento se tenha obtido sobre sua natureza física do que em quatro séculos, desde que seu antigo conquistador, Francisco de Orellana, se tornou o primeiro comandante branco a atravessá-lo". ${ }^{104} \mathrm{Em}$ bora requentando a gasta imagem da Amazônia como um território recém- 
descoberto, ele estava correto em vários pontos: nos cinco anos anteriores, os Estados Unidos tinham enviado à Amazônia centenas de burocratas, administradores, engenheiros, agrônomos e médicos, visando aumentar a produção de borracha; enviaram comissões para estudar as possibilidades de cultivo de gêneros alimentícios na bacia do Amazonas e os problemas de saúde, bem como para conduzir campanhas contra a malária; enviaram à floresta aviões de transporte pesado, para buscar borracha (Hanson, 1944, p.14). A Amazônia emergiu em monografias, livros de viagem, filmes e na propaganda de guerra, refletindo uma campanha mais ampla do governo norte-americano para solidificar a aliança interamericana, ainda que distorcida pelo idealismo romântico ou por preconceitos arraigados (Park, 1995, p.145). Agentes do governo dos Estados Unidos, geógrafos, estrategistas, ensaístas e propagandistas - incentivados por seus pares brasileiros - tentaram transformar a Amazônia em algo "legível" para o público norte-americano. ${ }^{105}$

Contudo, enquanto Hanson escrevia essas palavras para a Associação de Política Externa, a estrela da Amazônia já havia começado a perder seu brilho no horizonte político dos Estados Unidos. Em seu nível mais básico, a trajetória da Amazônia no imaginário dos Estados Unidos no tempo da guerra pode ser compreendida dentro do contexto de uma longa história de esforços de habitantes do hemisfério Norte para garantir o acesso às commodities tropicais. Durante o século XIX, os ingleses transferiram sementes da hevea da Amazônia para suas colônias asiáticas, numa estratégia para aumentar a produção da borracha e reduzir seus custos. ${ }^{106}$ Embora antes de Pearl Harbor a ameaça de interrupção do fornecimento por causa da guerra tenha provocado discussões nos Estados Unidos sobre a importância geopolítica de se diversificar os mercados da borracha e o desenvolvimento dos sintéticos, a subsequente interdição japonesa dos mercados tradicionais do Sudeste asiático fez que os agentes do governo norte-americano e cientistas se apressassem na busca por alternativas. Em meio a essa crise, a política do governo dos Estados Unidos priorizou a rápida criação de uma indústria sintética, ainda que o comércio da borracha crua na Amazônia também tenha recebido um estímulo efêmero, na forma de subsídios dos Estados Unidos.

Este ensaio, ao mesclar história diplomática, ambiental e cultural, sugere ainda que a evolução da Amazônia no imaginário norte-americano no tempo da guerra e as decisões políticas tomadas devem ser vistas sob uma lente analítica mais ampla. Como Arthur Whitaker observou, o ideal do hemisfério ocidental era um conceito geográfico enraizado em movimentos anticolonialistas do século XIX, que engendraram uma pletora de visões sociais, cultu- 
rais, econômicas e geopolíticas. ${ }^{107}$ De fato, a Amazônia testou os ideais enaltecidos de solidariedade hemisférica: para os céticos norte-americanos, a alteridade da floresta era um emblema do vasto e intransponível abismo entre os povos e culturas do Norte e do Sul, o qual ao mesmo tempo perpetuava, revelando as limitações, senão a futilidade, do pan-americanismo; para outros, a perfeita complementaridade da "fronteira" amazônica fortaleceria os Estados Unidos, econômica e moralmente, enquanto os ideais universais de justiça social e de democracia solidificariam os laços transnacionais, erradicariam a diferença cultural e reduziriam as desigualdades globais. Depois de Pearl Harbor, os responsáveis pela formulação das políticas dos Estados Unidos continuaram profundamente divididos sobre os objetivos do país na Amazônia: os liberais do New Deal preferiam a regulamentação estatal e subsídios para modernizar o comércio de borracha crua, alcançar reformas sociais duradouras e contrabalançar o controle monopolístico da emergente indústria da borracha sintética; os conservadores defendiam as prerrogativas empresariais na Amazônia, a concentração corporativa na indústria sintética e a manutenção da divisão internacional do trabalho.

As decisões políticas dos Estados Unidos durante a guerra, em relação à Amazônia, informaram e foram informadas por diferentes sensibilidades culturais que refletiam, ao mesmo tempo, necessidades domésticas contemporâneas e mitos arraigados sobre as regiões e populações tropicais. A clássica dicotomia do El Dorado ou "Inferno Verde" que polarizara as visões de forasteiros sobre a floresta tomou novas formas, num clima de militarismo global e de expansão do poder do Estado. Num nível conceitual mais amplo, o cisma entre os burocratas norte-americanos evoca observações acadêmicas, segundo as quais os projetos coloniais têm se baseado em tensões entre noções de incorporação e diferenciação. Como observam Stoler e Cooper, as políticas de reforma social dos Estados colonialistas europeus derivavam de um tênue equilíbrio entre programas que ligaram os interesses de grupos específicos ao poder colonial e políticas que manteriam uma série de distinções culturais escolhidas para conter e restringir as aspirações daqueles que seriam dominados. Dentro dos Estados colonialistas europeus, a tensão inevitavelmente levantava esta questão: até que ponto "civilizar" outros povos promoveria os interesses europeus e que tipo de consequência "civilizar em excesso" poderia trazer (Stoler \& Cooper, 1997, p.7-10). Com o maior envolvimento do governo dos Estados Unidos na Amazônia, gerado pela dependência da borracha, os gestores daquele país se digladiavam sobre até que ponto o "esforço civilizatório" seria apropriado para a floresta amazônica e seus povos. 
As visões da Amazônia no tempo da guerra também ressaltam como as percepções norte-americanas da floresta, moldadas por forças materiais, ideológicas e políticas, apresentaram permanências e mudanças ao longo do tempo. Na década de 1980, enquanto os gestores do Atlântico Norte tentavam lidar com os problemas da poluição industrial e do aquecimento global, a Amazônia reapareceu, em nova roupagem, na política e no imaginário popular nos Estados Unidos. Se norte-americanos defenderam a floresta tropical como um antídoto para o efeito estufa ou condenaram o desmatamento como sua causa, novos desafios geopolíticos haviam conferido novos significados à Amazônia. Ainda que em outro nível, as políticas e atitudes contemporâneas dos Estados Unidos em relação à Amazônia carregam as marcas indeléveis de antigas batalhas ideológicas. Ambientalistas, cujo ethos anticorporativo, próregulamentação e transcendentalista ecoa aquele dos progressistas do New Deal, defendem a conservação da floresta tropical como a forma adequada de manejo da natureza tropical e um contrapeso aos males do capitalismo industrial. Como Wallace, valem-se de uma mistura de apelos morais com argumentos científicos (agora focados na biodiversidade e na emissão de gás carbônico) para influenciar as políticas governamentais e a opinião pública nos Estados Unidos e no Brasil. E, como os progressistas do BEW, as ONGs ambientalistas do hemisfério Norte são frequentemente acusadas, no Brasil, de obstruírem interesses empresariais na Amazônia e de violarem a soberania nacional. Contudo, para muitos conservadores pró-empresas nos Estados Unidos o ambientalismo é a última artimanha liberal para impor regulamentação governamental sobre a indústria privada, e o aquecimento global, um embuste orquestrado por esquerdistas e pela Organização das Nações Unidas para destruir a supremacia econômica norte-americana. Como Jesse Jones, eles têm fortes laços com a indústria de energia e resistem à adoção multilateral de padrões universais para regular a interação humana com o ambiente natural. E, como sua contraparte da época da guerra, os conservadores contemporâneos nos Estados Unidos buscam manter a divisão internacional do trabalho por meio de políticas econômicas ortodoxas, como também pelo distanciamento ideológico entre o Norte e o Sul: a depravação tropical, que resiste à regeneração, ameaça contaminar a virtude do Norte. S. Fred Singer, um cientista que questionou a existência do aquecimento global, denuncia-o como uma trama de "cleptocratas do Terceiro Mundo" a fim de encontrar novas desculpas para pedir dinheiro ao Ocidente. ${ }^{108}$ Em suma, não obstante nos Estados Unidos frequentemente se imagine a Amazônia como atemporal (e 
desabitada), sua representação tem raízes históricas em conflitos sociopolíticos sobre os usos e os significados da natureza tropical.

A historiografia recente sobre a Amazônia produzida por norte-americanos também reflete as mudanças nos significados da região, ao mesmo tempo em que contribui para elas. Durante a Guerra Fria, quando acadêmicos dos Estados Unidos questionavam as teorias das ciências sociais e os mantras políticos sobre o subdesenvolvimento da América Latina, o trabalho de Barbara Weinstein (1983) examinou os modos de produção nos seringais para entender o engessamento do processo de transição da região para o capitalismo. Alguns anos mais tarde, com as preocupações ambientais ganhando maior proeminência nos debates políticos e no método historiográfico nos Estados Unidos, Warren Dean (1987) se concentrou nos desafios botânicos para o cultivo de seringueiras na Amazônia para entender as peculiaridades desse comércio. E minha pesquisa sobre a Amazônia no imaginário dos Estados Unidos no período da Segunda Guerra Mundial, conduzida em meio a uma desastrosa guerra no Iraque que levou à morte mais de 4 mil soldados norteamericanos e mais de 90 mil civis iraquianos, foi assombrada pelas origens e consequências da dependência de matérias-primas na indústria automotiva e pelos dramas e tramas que os norte-americanos instigaram, interna e externamente, ao lidar com essa realidade.

\section{(Tradução: Manuel Amaral Bueno e Regina Horta Duarte)}

\section{Agradecimento}

National Endowment for the Humanities Fellowship; Andrew W. Mellon Foundation Faculty Fellowship in Latin American Studies; Rockefeller Archive Center Research Grant; Franklin and Eleanor Roosevelt Institute Research Grant; University of Texas at Austin Summer Research Assignment. E agradeço a Regina Horta Duarte e Manuel Amaral Bueno pela tradução exemplar.

\section{NOTAS DOS TRADUTORES}

${ }^{a}$ No original, o termo usado é Wilderness. É um termo intraduzível para o português, podendo significar tanto uma grande região inculta e em condições originais, como uma imensa floresta ou outra vegetação nativa, assim como áreas desérticas e vazias de ocupação humana. 


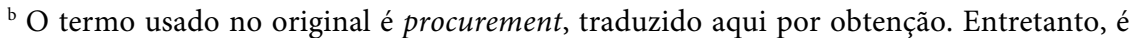
importante ressaltar que o sentido da palavra inglesa é muito mais amplo, envolvendo um conjunto de atos administrativos e logísticos de estratégias e escolhas de fornecimento.

${ }^{c}$ A palavra usada por Jones (frijole) designa um gênero de feijão cultivado no México e em outros países da América Espanhola, mas não no Brasil.

\section{NOTAS}

${ }^{1}$ Ver, por exemplo, HILTON, Stanley E. "Brazilian Diplomacy and the Washington-Rio de Janeiro 'Axis' during the World War II Era”, Hispanic American Historical Review, v.59, n.2, May 1979, p.201-231; MOURA, Gerson. Autonomia na dependência: a política externa brasileira de 1935 a 1942. Rio de Janeiro: Nova Fronteira, 1980; McCANN, Frank D. The Brazilian-American Alliance, 1937-1945. Princeton: Princeton University Press, 1974; CORSI, Francisco Luiz. Estado Novo: política externa e projeto nacional. São Paulo: Ed. Unesp; Fapesp, 1999.

${ }^{2}$ Ver HUMPHREYS, R. A. Latin America and the Second World War. London: Athlone, 1981, p.70.

${ }^{3}$ Ver, por exemplo, GONDIM, Neide. A invenção da Amazônia. São Paulo: Marco Zero, 1994; SLATER, Candace. Entangled Edens: visions of the Amazon. Berkeley: University of California Press, 2002; MALIGO, Pedro. Land of Metaphorical desires: the representation of Amazonia in Brazilian literature. New York: Peter Lang, 1998.

${ }^{4}$ Ver, por exemplo, KAPLAN, Amy; PEASE, Donald E. (Ed.). Cultures of United States Imperialism. Durham: Duke University Press, 1993; JOSEPH, Gilbert M.; LEGRAND, Catherine C.; SALVATORE, Ricardo D. (Ed.). Close encounters of empire: writing the cultural history of U.S.-Latin American relations. Durham: Duke University Press, 1998; TOTA, Antonio Pedro. O imperialismo sedutor: a americanização do Brasil na época da Segunda Guerra. São Paulo: Companhia das Letras, 2000.

${ }^{5}$ Ver ROCK, David. "War and Postwar intersections: Latin America and the United States”. In: ROCK, David (Ed.). Latin America in the 1940s: war and postwar transitions. Berkeley and Los Angeles: University of California Press, 1994. p.26.

${ }^{6}$ Ver PARK, James William. Latin American underdevelopment: a History of perspectives in the United States, 1870-1965. Baton Rouge: Louisiana State University, 1995; PIKE, Frederick B. The United States and Latin America: myths and stereotypes of civilization and nature. Austin: University of Texas Press, 1998.

${ }^{7} \mathrm{O}$ naturalista britânico Henry Walter Bates, por exemplo, ansiou pela civilização europeia da Amazônia, destinada a produzir "uma nova e gloriosa raça humana abaixo do Equador". Citado por SLATER, Entangled Edens, p.41; Louis Agassiz aspirou a um influxo mais vigoroso de "sangue" do hemisfério Norte para o Amazonas, onde aqueles que "se passavam por brancos" eram portugueses, que tinham uma tendência para se tornarem "india- 
nizados em seus hábitos". Citado por STEPAN, Nancy Leys. Picturing tropical nature. Ithaca: Cornell University Press, 2001. p.10.

${ }^{8}$ ROCK, 1994, p.23; e GUERANT, Edward O. Roosevelt's Good Neighbor Policy. Albuquerque: University of New Mexico Press, 1950. p.195.

${ }^{9} \mathrm{O}$ objetivo específico de várias dessas agências foi bem estudado no caso do Brasil. Sobre o OIAA, ver TOTA, 2000; e CAMPOS, André Luiz Vieira de. Políticas Internacionais de Saúde na Era Vargas. Rio de Janeiro: Fiocruz, 2006; sobre a USDA e a FAR, ver DEAN, Warren. Brazil and the struggle for rubber: a study in environmental history. Cambridge: Cambridge University Press, 1987.

${ }^{10}$ REICH, Cary. The life of Nelson A. Rockefeller: worlds to conquer, 1908-1958. New York: Doubleday, 1996. p.195.

${ }^{11}$ MARSHALL, Jonathan. To have and have not: southeast Asian raw materials and the origins of the Pacific War. Berkeley: University of California Press, 1995. p.1-2; e KNORR, K. E. World rubber and its regulation. Stanford: Stanford University Press, 1945. p.3.

${ }^{12}$ TUTTLE, Jr., William M. “The birth of an industry: the synthetic rubber 'mess' in World War II”, Technology and Culture, v.22, n.1, Jan. 1981, p.65.

${ }^{13}$ KNORR, K. E. World rubber and its regulation. Stanford: Stanford University Press, 1945. p.3, 9.

${ }^{14}$ HESSEL, M. S.; MURPHY, W. J.; HESSEL, F. A. Strategic materials in hemisphere defense. New York: Hastings House, 1942. p.7.

${ }^{15}$ CORONIL, Fernando. The Magical State: nature, money, and modernity in Venezuela. Chicago: University of Chicago Press, 1997. p.29.

${ }^{16}$ APODACA, Joseph L. "Can the Americas live alone?", Agriculture in the Americas, Feb. 1941, p.10.

${ }^{17}$ MARTINELLO, Pedro. A "batalha da borracha" na Segunda Guerra Mundial. Rio Branco: Edufac, 2004. p.85, 209.

${ }^{18}$ HARVEY, David. Justice, nature and the geography of difference. Cambridge (Mass.); Oxford (UK): Blackwell, 1996. p.232.

${ }^{19}$ GUNTHER, John. Inside Latin America. New York \& London: Harper \& Brothers, 1941. p.14-15.

${ }^{20}$ AHL, Frances Norene. Two thousand miles up the Amazon. Boston: The Christopher Publishing House, 1941. p.131.

${ }^{21}$ DEAN, Warren. Brazil and the struggle for rubber: a study in environmental history. Cambridge: Cambridge University Press, 1987. p.87-89; BRANDES, E. W. "Rubber on the Rebound - East to West", Agriculture in the Americas, Apr. 1941, p.4; MALLERY, D. "Rubber Studies Begin", Agriculture in the Americas, Dec. 1941, p.5-6; e LANGFORD, M. H. "Science's Fight for Healthy Hevea", Agriculture in the Americas, Aug. 1944, p.151158. 
${ }^{22}$ Samuel Herman to Monroe Oppenheimer, Nov. 2, 1942. National Archives [daqui em diante NA], RG169 Foreign Economic Administration, Board of Economic Warfare, General Counsel, Box 39.

${ }^{23}$ Ver prefácio de Eduardo Viveiros de Castro em ARNT, Ricardo Azambuja; SCHWARTZMAN, Stephan. Um artifício orgânico: transição na Amazônia e ambientalismo. Rio de Janeiro: Rocco, 1992. p.22.

${ }^{24}$ APPADURAI, Arjun. "Introduction: Commodities and the Politics of Value". In: APPADURAI, Arjun (Ed.). The social life of things: commodities in cultural perspective. Cambridge: Cambridge University Press, 1986. p.5.

${ }^{25}$ KLEINMAN, Mark L. A world of hope, a world of fear: Henry A. Wallace, Reinhold Niebuhr, and American liberalism. Columbus: Ohio State University Press, 2000. p.88-90, 113; BLUM, John Morton. V was for victory: politics and American culture during World War II. New York: Harcourt Brace Jovanovich, 1976. p.287.

${ }^{26}$ GELLMAN, Irwin F. Good Neighbor Diplomacy. Baltimore: Johns Hopkins University Press, 1979. p.157-158.

${ }^{27}$ BEALS, Carleton. Pan America. Boston: Houghton Mifflin Company, 1940. p.492.

${ }^{28}$ Ver, por exemplo, NASH, Roderick. Wilderness and the American mind. 3.ed. New Haven: Yale University Press, 1982; KLEIN, Kerwin Lee. Frontiers of historical imagination: narrating the European conquest of native America, 1890-1990. Berkeley: University of California Press, 1997.

${ }^{29}$ Sobre as limitações da fronteira como símbolo pan-americano, no Brasil, durante essa época, ver WEGNER, Robert. A conquista do oeste: a fronteira na obra de Sérgio Buarque de Holanda. Belo Horizonte: Ed. UFMG, 2000.

${ }^{30}$ ROOSEVELT, Nicholas. Wanted: Good Neighbors, the need for closer ties with Latin America. New York: National Foreign Trade Council, 1939. p.4.

${ }^{31}$ Ver, por exemplo, GREEN, Philip Leonard. Our Latin American Neighbors. New York: Hastings House, 1941. p.72.

${ }^{32}$ HANSON, Earl Parker. Journey to Manaos. New York: Reynal \& Hitchcock, 1938. p.307.

${ }^{33}$ BEALS, Carleton. "Future of the Amazon", Survey Graphic, Mar. 1941, p.149-150; 194195. Para uma biografia crítica de Beals, ver BRITTON, John A. Carleton Beals: a radical journalist in Latin America. Albuquerque: University of New Mexico Press, 1987.

${ }^{34}$ DOENECKE, Justus D. (Ed.). In danger undaunted: the Anti-Interventionist Movement of 1940-1941 as Revealed in the Papers of the America First Committee. Stanford (CA): Hoover Institution Press, 1990. p.6.

${ }^{35}$ Estou aqui me inspirando na análise de Richard Drayton sobre as coleções botânicas do Império Britânico como originadas, em parte, pelas visões providencialistas da abundância edênica. Ver DRAYTON, Richard. Nature's government: science, imperial Britain, and the 'Improvement' of the World. New Haven: Yale University Press, 2000. 
${ }^{36}$ Ver UNITED STATES TARIFF COMMISSION, Rubber: possibilities of producing rubber in the United States and rubber conservation, Washington, Sep. 1941; Sobre o relatório da U. S. Army and Navy Munitions em 1940, ver MARSHALL, 1995, p.13.

${ }^{37}$ Bricks without Straw: the story of synthetic rubber. Akron: B. F. Goodrich Co., 1944. p.11.

${ }^{38}$ Ver RUSSELL, Joseph A. "Fordlandia and Belterra, rubber plantations on the Tapajos River, Brazil”, Economic Geography, v.18, n.2, Apr. 1942, p.125-145.

${ }^{39}$ Inspiro-me aqui em LOMNITZ-ADLER, Claudio. "Concepts for the Study of Regional Culture”, American Ethnologist, v.18, n.2, May 1991, p.200.

${ }^{40}$ LA VARRE, William. Southward Ho!: a treasure hunter in South America. New York: Doubleday, Doran \& Co., 1940. p.115. No mesmo gênero, ver BROWN, Rose; BROWN, Bob. Amazing Amazon. New York: Modern Age Books, 1942. p.165.

${ }^{41}$ WITHERSPOON, Anna. Let's see South America. Dallas: The Southern Publishing Company, 1939. p.446, 459.

${ }^{42}$ Ver DEAN, Brazil and the struggle for rubber, 1987, p.87; e MORRIS, Peter J. T. The American Synthetic Rubber Research Program. Philadelphia: University of Pennsylvania Press, 1989. p.9.

${ }^{43}$ PINTO, Nelson Prado Alves. Política da borracha no Brasil: a falência da borracha vegetal. São Paulo: Hucitec; Conselho Regional de Economia, 1984. p.50-56.

${ }^{44}$ Ver ECKES, Alfred E. The United States and the global struggle for minerals. Austin: University of Texas Press, 1979. p.103-104; e KRASNER, Stephen D. Defending the national interest: raw materials investments and U.S. foreign policy. Princeton: Princeton University Press, 1978. p.101-106.

${ }^{45}$ Sobre a batalha da borracha, ver MARTINELLO, 2004; DEAN, Brazil and the struggle for rubber, 1987; SECRETO, Maria Veronica. Soldados da borracha: trabalhadores entre o sertão e a Amazônia no governo Vargas. São Paulo: Fundação Perseu Abramo, 2007; MORALES, Lucia Arrais. Vai e vem, vira e volta: as rotas dos soldados da borracha. São Paulo: Annablume; Fortaleza: Secult, 2002.

${ }^{46}$ WEINSTEIN, Barbara S. The Amazon rubber boom, 1850-1920. Stanford (Calif.): Stanford University Press, 1983. p.179.

${ }^{47}$ HERTZ, John. "Attention is being called to the purchase and securing of wild rubber from Central and South America..." n.d. Franklin Delano Roosevelt Library [daqui em diante FDRL], Rubber Survey Committee, 1942, Documents and Report, Box 10.

${ }^{48}$ R. B. Bogardus to Mr. Bicknell, Washington, Oct. 14, 1942 NA, RG234. Records of the Reconstruction Finance Corporation [RFC], RDC, Central Files 1942-1949, Booth Steamship Company thru Brazil - Gen. Cor. 10/42 - 12/31/42 Parts 3 [Box 31] [52].

${ }^{49}$ GREEN, David. The containment of Latin America: a history of the myths and realities of the good neighbor policy. Chicago: Quadrangle Books, 1971. p.196. Ver também a corres- 
pondência de Arthur Paul, Chief of Office, to John Worcester, n.d. NA, RG169 Foreign Economic Administration, Board of Economic Warfare, General Counsel, Box 38.

${ }^{50}$ WALKER, J. Samuel. Henry A. Wallace and American foreign policy. Westport (Conn.): Greenwood Press, 1976. p.94-95.

${ }^{51}$ M. B. Wolf, Chief Counsel, Rubber Division of BEW to R. J. Levy, Assistant Chief, Rubber Division, Nov. 16, 1942, NA, RG169 Foreign Economic Administration, Board of Economic Warfare, General Counsel, Box 41.

${ }^{52}$ Milo Perkins to Bernard M. Baruch, James B. Conant, and Carl T. Compton, Aug. 16, 1942; FDRL, Rubber Survey Committee, 1942, Box 3, Documents, Vols. I-III.

${ }^{53}$ Statement by Vice President Wallace, Chairman of the Board of Economic Warfare, as Originally Prepared for the Senate Committee on Appropriations. FDRL, OF4226, Board of Economic Warfare 1943, Box 1.

${ }^{54}$ Milo Perkins to William Jeffers, Jan. 23, 1943, NA, RG169 Foreign Economic Administration, Board of Economic Warfare, General Counsel, Box 41; H. A. Wallace to W. L. Clayton, June 19, 1942 FDRL, Henry A. Wallace Papers as Vice President 1941-45, General Correspondence Box 14; SCHAPSMEIER, Edward L. Prophet in politics: Henry A. Wallace and the war years, 1940-1965. Ames (Iowa): University Press, 1971. p.58.

${ }^{55}$ BLUM, 1976, p.281; BRODY, David. "The New Deal and World War II". In: Braerman, John; Bremner, Robert H.; BRODY, David (Ed.). The New Deal: the national level. Columbus (OH): Ohio State University Press, 1975. p.300.

${ }^{56}$ Ver WALKER, 1976, p.94-95; BLUM, 1976, p.281-282; KLEINMAN, 2000, p.139-147; ROSENBERG, Emily S. Spreading the American dream: American economic and cultural expansion, 1890-1945. New York: Hill and Wang, 1982. p.170.

${ }^{57}$ WALLACE, Henry A. "Economic Warfare - the war behind the war", Army and Navy Journal, Aug. 29, 1942. FDRL, OF 4226, Board of Economic Warfare 1942, Box 1; H. A. Wallace to W. L. Clayton, July 2, 1942, FDRL, Henry A. Wallace Papers as Vice President 1941-45, General Correspondence Box 14; Board of Economic Warfare Memorandum: Obstacles to Increased Rubber Production in South and Central America, Aug. 31, 1942, FDRL, Rubber Survey Committee, 1942, Documents and Reports, Box 10.

${ }^{58}$ John W. Bicknell, Vice President Rubber Reserve Company, to D. H. Allen, Special Assistant to the President, Rubber Reserve Company, Washington, Jan. 13, 1943; Leonard H. Heller, Chief, Rubber Division, Board of Economic Warfare to John W. Bicknell, Washington, Jan. 12, 1943. NA, RG234 Records of the Reconstruction Finance Corporation [RFC], RDC, Country Correspondence File, 1942-45, Brazil-Miscellaneous.

59 "There is another misunderstanding which I wish to correct..." n.d., NA, RG169 Foreign Economic Administration, Board of Economic Warfare, General Counsel, Box 40.

${ }^{60}$ Citado por REICH, 1996, p.240; sobre a colaboração entre o BEW e o OIAA, ver HOFFMAN, Elizabeth Cobbs. The rich neighbor policy: Rockefeller and Kaiser in Brazil. New Haven: Yale University Press, 1992. p.39. 
${ }^{61}$ Robert J. Levy to Douglas Allen, Oct. 3, 1942. NA, RG234 Records of the Reconstruction Finance Corporation [RFC], RDC, Country Correspondence File, 1942-45, Brazil-Miscellaneous.

${ }^{62}$ Leonard H. Heller to Douglas Allen, Dec. 9, 1942. NA, RG169 Foreign Economic Administration, Board of Economic Warfare, General Counsel, Box 41.

${ }^{63}$ Comments on the Statement Made by Jesse Jones, Secretary of Commerce, on July 5, 1943. FDRL, Henry A. Wallace, Papers as Vice President 1941-45, General Correspondence Box 61.

${ }^{64}$ Arthur Paul, BEW Acting Assistant Director in Charge of Office of Imports to Milo Perkins, Jan. 13, 1943. NA, RG169 Foreign Economic Administration, Board of Economic Warfare, General Counsel, Box 40. Ver também JONES, Jesse H. Fifty billion dollars: my thirteen years with the RFC, 1932-1945. New York: MacMillan, 1951. p.428-429; REICH, 1996, p.183.

${ }^{65}$ Paul R. Hays, Chief, Rubber Division, Development Branch to Morris S. Rosenthal, Assistant Director, 1942. NA, RG169 Foreign Economic Administration, Board of Economic Warfare, General Counsel, Box 41.

${ }^{66}$ Leonard H. Heller to Douglas Allen, Dec. 9, 1942. NA, RG169 Foreign Economic Administration, Board of Economic Warfare, General Counsel, Box 41.

67 "Use of Labor Clauses in U. S. Contracts for Procurement of Strategic Materials" Spring 1943. RG 169 Records of the Foreign Economic Administration, Office of Administrator, Records Analysis - Historical File, Box 6.

${ }^{68}$ Sobre os contratos oficiais e a falta de aplicação pelo regime de Vargas, ver LENHARO, Alcir. Colonização e trabalho no Brasil: Amazônia, Nordeste e Centro-Oeste: os anos 30. Campinas (SP): Ed. Unicamp, 1985.

${ }^{69}$ Sobre o Projeto de saúde pública na Amazônia, ver CAMPOS, André Luiz Vieira de. Políticas internacionais de saúde na Era Vargas. Rio de Janeiro: Fiocruz, 2006.

${ }^{70}$ Arthur Paul, Chief of Office, to John Worcester, n.d. NA, RG169 Foreign Economic Administration, Board of Economic Warfare, General Counsel, Box 38.

71 “There is another misunderstanding which I wish to correct...” n.d. NA, RG169 Foreign Economic Administration, Board of Economic Warfare, General Counsel, Box 40.

${ }^{72}$ BLUM, John Morton (Ed.). The price of vision: the diary of Henry A. Wallace, 1942-1946. Boston: Houghton Mifflin, 1973. p.110.

${ }^{73}$ Harold W. Starr, Assistant General Counsel to Morris S. Rosenthal, Assistant Director, BEW, June 22, 1942. NA, RG169 Foreign Economic Administration, Board of Economic Warfare, General Counsel, Box 40.

74 "Use of Labor Clauses in U. S. Contracts for Procurement of Strategic Materials" Spring 1943. NA, RG 169 Records of the Foreign Economic Administration, Office of Administrator, Records Analysis - Historical File, Box 6. 
${ }^{75}$ Harold W. Starr, Assistant General Counsel to Morris S. Rosenthal, Assistant Director, BEW, June 22, 1942. RG169 Foreign Economic Administration, Board of Economic Warfare, General Counsel, Box 40.

${ }^{76}$ Arthur Paul, Chief of Office, to John Worcester, n.d. NA, RG169 Foreign Economic Administration, Board of Economic Warfare, General Counsel, Box 38.

${ }^{77}$ John W. Bicknell, Vice President Rubber Reserve Company, to D. H. Allen, Special Assistant to the President, Rubber Reserve Company, Washington, Jan. 13, 1943; Leonard H. Heller, Chief, Rubber Division, Board of Economic Warfare to John W. Bicknell, Washington, Jan. 12, 1943. NA, RG234 Records of the Reconstruction Finance Corporation [RFC], RDC, Country Correspondence File, 1942-45, Brazil-Miscellaneous.

78 "Use of Labor Clauses in U. S. Contracts for Procurement of Strategic Materials" Spring 1943. NA, RG 169 Records of the Foreign Economic Administration, Office of Administrator, Records Analysis - Historical File, Box 6.

${ }^{79}$ WILSON, Charles Morrow. Trees \& test tubes: the story of rubber. New York: H. Holt and Company, 1943. p.160-162, 248-252.

${ }^{80}$ Ver H. A. Wallace to E. N. Bresman, Director, Agricultural Division, OCIAA, Oct. 1, 1942. FDRL, Henry A. Wallace Papers as Vice President 1941-45, General Correspondence Box 9; e BLUM (Ed.), 1973, p.82, 188-189.

${ }^{81}$ HOFFMAN, 1992, p.59; e MOURA, Gerson. Tio Sam chega ao Brasil. São Paulo: Brasiliense, 1984. p.56.

${ }^{82}$ Henry Wallace to Sumner Welles and Jesse Jones, Washington (DC), Mar. 11, 1942. FDRL, Sumner Welles Papers, Latin American Files, 1919-1943, Box 169.

${ }^{83}$ Ver McCANN, 1974, p.264; e BANDEIRA, Moniz. Presença dos Estados Unidos no Brasil. Rio de Janeiro: Civilização Brasileira, 1973. p.285.

${ }^{84}$ Arthur Paul, BEW Acting Assistant Director in Charge of Office of Imports to Milo Perkins, Jan. 13, 1943. NA, RG169 Foreign Economic Administration, Board of Economic Warfare, General Counsel, Box 40; Leonard H. Heller to Douglas Allen, Dec. 9, 1942. NA, RG169 Foreign Economic Administration, Board of Economic Warfare, General Counsel, Box 41; D. H. Allen, President, RDC, Memorandum Prepared by Mr. Douglas H. Allen in Response to a Request for Information as to the "Amazon Project" and his Relationship Thereto, Jan. 14, 1944. Seeley G. Mudd Manuscript Library, Princeton University. Rubber Development Corporation, Amazon Division Records, 1942-1945, Box 3, Folder 10, Doc. 6.

${ }^{85}$ COOPER, Frederick; STOLER, Ann Laura. "Between Metropole and Colony: rethinking a research agenda”. In: COOPER, Frederick; STOLER, Ann Laura (Ed.). Tensions of empire: colonial cultures in a bourgeois world. Berkeley: University of California Press, 1997. p.5.

${ }^{86}$ Sobre os desafios históricos enfrentados pelo modo capitalista de produção nos serin- 
gais, ver WEINSTEIN, 1983, p.157; e SANTOS, Roberto. História econômica da Amazônia, 1800-1920. São Paulo: T. A. Queiroz, 1980. p.114-115.

${ }^{87}$ Por exemplo, quando o BEW levantou objeções contra a proposta de um contrato entre a United Fruit Company e a Defense Supplies Corporation para a produção de abacá [Manila hemp] na América Central, com base na excessiva flexibilidade estendida à empresa para que plantasse uma área mínima de abacá, Will Clayton defendeu a United Fruit: "Eles conhecem o país, são as únicas pessoas do hemisfério ocidental que já têm experiência considerável em abacá, e consideramos improvável encontrar em outro lugar a capacitação técnica e a experiência necessárias para controlar essa operação rapidamente". Ver Wallace to Clayton, Jan. 16, 1942; e Clayton to Wallace, Jan. 19, 1942. FDRL, Henry A. Wallace Papers as Vice President 1941-45, General Correspondence Box 14.

${ }^{88}$ D. H. Allen, Chairman, Otis Astoria Corporation to W. L. Clayton, Deputy Federal Loan Administrator, Federal Loan Agency, Feb. 24, 1942 [52]; S. M. McAshan, Jr. to W. L. Clayton, Sep. 18, 1942. RG234 Records of the Reconstruction Finance Corporation [RFC], RDC, Central Files 1942-1949, Brazil, Reports 12/31/41 -9/30/42 thru Brazil, Reports 4/1/43 - 6/30/43, Box 71; D. H. Allen, President, RDC, Memorandum Prepared by Mr. Douglas H. Allen in Response to a Request for Information as to the "Amazon Project" and his Relationship Thereto, Jan. 14, 1944. Seeley G. Mudd Manuscript Library, Princeton University. Rubber Development Corporation, Amazon Division Records, 1942-1945, Box 3, Folder 10, Doc. 6.

${ }^{89}$ Douglas H. Allen, President, Rubber Development Corporation, Report on the Operations of Rubber Development Corporation, Feb. 23, 1943 to Aug. 31, 1944, Washington, Sep. 30, 1944. Seeley G. Mudd Manuscript Library, Princeton University. Rubber Development Corporation, Amazon Division Records, 1942-1945, Box 3, Folder RDC - History and Organization.

${ }^{90}$ Ver, por exemplo, John Worcester to Alan M. Bateman, La Paz, Bolivia, Dec. 8, 1942; John Worcester to Alan M. Bateman, La Paz, Bolivia, Oct. 29, 1942; e Memorandum. Subject: Bolivian Situation; Worcester File, Dec. 24, 1942. NA, RG169 Foreign Economic Administration, Board of Economic Warfare, General Counsel, Box 38.

${ }^{91}$ D. H. Allen, Chairman, Otis Astoria Corporation to W. L. Clayton, Deputy Federal Loan Administrator, Federal Loan Agency, Feb. 24, 1942. NA, RG234 Records of the Reconstruction Finance Corporation [RFC], RDC, Central Files 1942-1949, Booth Steamship Company thru Brazil - Gen. Cor. 10/42 - 12/31/42 Parts 3 [Box 31].

92 W. L. C. Clayton, Assistant Secretary of Commerce, to Morris S. Rosenthal, Assistant Director of the BEW, Sep. 21, 1942. NA, RG169 Foreign Economic Administration, Board of Economic Warfare, General Counsel, Box 41.

${ }^{93}$ S. M. McAshan to W. L. Clayton, Sep. 18, 1942. NA, RG169 Foreign Economic Administration, Board of Economic Warfare, General Counsel, Box 41.

${ }^{94}$ D. H. Allen, President, RDC, Memorandum Prepared by Mr. Douglas H. Allen in Response to a Request for Information as to the "Amazon Project" and his Relationship The- 
reto, Jan. 14, 1944. Seeley G. Mudd Manuscript Library, Princeton University. Rubber Development Corporation, Amazon Division Records, 1942-1945, Box 3, Folder 10, Doc. 6.

${ }^{95}$ BOYLE, Stanley E. "Government promotion of monopoly power: an examination of the sale of the synthetic rubber industry", The Journal of Industrial Economics, v.9, n.2, Apr. 1961, p.151-169.

${ }^{96}$ POLENBERG, Richard. War and society: the United States, 1941-1945. Philadelphia: Lippincott, 1972. p.18.

${ }^{97}$ GUSTIN, Harold. "Rio Negro Diary”. Seeley G. Mudd Manuscript Library, Princeton University. Rubber Development Corporation, Amazon Division Records, 1942-1945, Box 12.

${ }^{98}$ Ver, por exemplo, ARNOLD, David. The problem of nature: environment, culture and European expansion. Oxford (UK); Cambridge (MA): Blackwell, 1996; STEPAN, 2001, p.36; KAPLAN, Amy. "Left alone with America': the absence of Empire in the study of American culture”. In: KAPLAN, Amy; PEASE, Donald E. (Ed.). Cultures of United States Imperialism. Durham: Duke University Press, 1993. p.14-15.

${ }^{99}$ PHILLIPS, Henry Albert. Brazil: bulwark of inter-American relations. New York: Hastings House, 1945. p.28-29.

${ }^{100}$ D. H. Allen to Mr. Crowley, Washington, Sept 5, 1944. Seeley G. Mudd Manuscript Library, Princeton University. Rubber Development Corporation, Amazon Division Records, 1942-1945, Box 3, Folder 2.

${ }^{101}$ Informational Bulletin No. 3, Mar. 15, 1943, Rubber Development Corp, by Everett G. Holt, Commercial Research, Seeley G. Mudd Manuscript Library, Princeton University. Rubber Development Corporation, Amazon Division Records, 1942-1945, Box 3, Folder RDC Information Bulletins.

${ }_{102}$ MORRIS, Peter J. T. The American Synthetic Rubber Research Program. Philadelphia: University of Pennsylvania Press, 1989, p.8; TUTTLE, 1981, p.62-65. Sobre a contribuição de cientistas, químicos e botânicos, para a desigualdade global, ver HEADRICK, Daniel R. "Botany, Chemistry, and tropical development", Journal of World History, v.7, n.1, 1996, p.14.

${ }^{103}$ W. N. Walmsley, Jr., Amazon Rubber program, Enclosure to Dispatch 13146 of Oct. 18,1943 from the Embassy at Rio de Janeiro, NA, RG234 Records of the Reconstruction Finance Corporation [RFC], RDC, Central Files 1942-1949, Brazil-Reports 7/1/43 8/31/43 thru Brazil-Reports 11/1/43 - 12/31/43 [Box 72].

${ }^{104}$ HANSON, Earl Parker. The Amazon: a new frontier? New York: Foreign Policy Association, 1944. p.14.

${ }^{105}$ McCann nota que poucos brasileiros visitavam os Estados Unidos, ao passo que os norte-americanos frequentemente confundiam Rio de Janeiro e Buenos Aires, e o samba com o tango. Ver McCANN, 1974, p.248-249. James C. Scott usa o termo "legibility" para se referir aos esforços governamentais para reunir informações sobre população e paisagens, 
os quais inevitavelmente simplificavam excessivamente as realidades sociais. Ver SCOTT, James C. Seeing like a state: how certain schemes to improve the human condition have failed. New Haven: Yale University Press, 1998.

${ }^{106}$ Sobre as estratégias das potências industriais visando aumentar a produção e diminuir os custos das mercadorias de origem tropical, ver HEADRICK, The tentacles of progress: technology transfer in the Age of Imperialism, 1850-1940. Oxford: Oxford University Press, 1988. p.249.

${ }^{107}$ WHITAKER, Arthur Preston. The Western Hemisphere idea: its rise and decline. Ithaca (NY): Cornell University Press, 1954. p.2.

${ }^{108}$ Citado por PATTERSON, Matthew. Global Warming and Global Politics. London \& New York: Routledge, 1996. p.2.

Artigo recebido em fevereiro de 2009. Aprovado em março de 2009. 